\title{
Polar processing in a split vortex: Arctic ozone loss in early winter 2012/2013
}

\author{
G. L. Manney ${ }^{1,2}$, Z. D. Lawrence ${ }^{2}$, M. L. Santee ${ }^{3}$, N. J. Livesey ${ }^{3}$, A. Lambert ${ }^{3}$, and M. C. Pitts ${ }^{4}$ \\ ${ }^{1}$ NorthWest Research Associates, Socorro, NM, USA \\ ${ }^{2}$ New Mexico Institute of Mining and Technology, Socorro, NM, USA \\ ${ }^{3}$ Jet Propulsion Laboratory, California Institute of Technology, Pasadena, CA, USA \\ ${ }^{4}$ NASA Langley Research Center, Hampton, VA, USA
}

Correspondence to: G. L. Manney (manney@nwra.com)

Received: 25 January 2015 - Published in Atmos. Chem. Phys. Discuss.: 23 February 2015

Revised: 21 April 2015 - Accepted: 28 April 2015 - Published: 19 May 2015

\begin{abstract}
A sudden stratospheric warming (SSW) in early January 2013 caused the Arctic polar vortex to split and temperatures to rapidly rise above the threshold for chlorine activation. However, ozone in the lower stratospheric polar vortex from late December 2012 through early February 2013 reached the lowest values on record for that time of year. Analysis of Aura Microwave Limb Sounder (MLS) trace gas measurements and Cloud-Aerosol Lidar and Infrared Pathfinder Satellite Observations (CALIPSO) polar stratospheric cloud (PSC) data shows that exceptional chemical ozone loss early in the 2012/13 Arctic winter resulted from a unique combination of meteorological conditions associated with the early-January 2013 SSW: unusually low temperatures in December 2012, offspring vortices within which air remained well isolated for nearly 1 month after the vortex split, and greater-than-usual vortex sunlight exposure throughout December 2012 and January 2013. Conditions in the two offspring vortices differed substantially, with the one overlying Canada having lower temperatures, lower nitric acid $\left(\mathrm{HNO}_{3}\right)$, lower hydrogen chloride, more sunlight exposure/higher $\mathrm{ClO}$ in late January, and a later onset of chlorine deactivation than the one overlying Siberia. MLS $\mathrm{HNO}_{3}$ and CALIPSO data indicate that PSC activity in December 2012 was more extensive and persistent than at that time in any other Arctic winter in the past decade. Chlorine monoxide ( $\mathrm{ClO}$, measured by MLS) rose earlier than previously observed and was the largest on record through mid-January 2013. Enhanced vortex $\mathrm{ClO}$ persisted until midFebruary despite the cessation of PSC activity when the SSW
\end{abstract}

started. Vortex $\mathrm{HNO}_{3}$ remained depressed after PSCs had disappeared; passive transport calculations indicate vortexaveraged denitrification of about 4 parts per billion by volume. The estimated vortex-averaged chemical ozone loss, $\sim 0.7-0.8$ parts per million by volume near $500 \mathrm{~K}(\sim 21 \mathrm{~km})$, was the largest December/January loss in the MLS record from $2004 / 05$ to $2014 / 15$.

\section{Introduction}

The Arctic winter stratosphere exhibits extreme interannual variability in dynamical conditions. Because chlorinecatalyzed chemical ozone loss in the polar winter lower stratosphere depends strongly on temperatures and vortex confinement (e.g., Schoeberl et al., 1992; Solomon, 1999), the varying meteorological environment is reflected in large variations in ozone loss. Sudden stratospheric warmings (SSWs) in the Arctic cause temperatures to rise abruptly and the westerly winter circulation to reverse to easterly; they are one of the predominant drivers of Arctic winter variability (e.g., Charlton and Polvani, 2007; Charlton-Perez et al., 2008, and references therein). During "major" SSWs (SSWs in which the zonal mean zonal winds at $10 \mathrm{hPa}$ reverse from westerly to easterly poleward of $60^{\circ}$ ), lower stratospheric temperatures usually rise rapidly above the threshold for conversion of chlorine to "active" (ozone-destroying) forms (e.g., Manney et al., 2005; Kuttippurath et al., 2010; Kuttippurath and Nikulin, 2012). The period with conditions 
conducive to chlorine activation in the Arctic ranges from a few days (in winters with strong SSWs in December, e.g., Manney et al., 1999a, 2005) to over 4 months (in the exceptional 2010/11 winter, e.g., Manney et al., 2011; Sinnhuber et al., 2011; Arnone et al., 2012; Kuttippurath et al., 2012; Hommel et al., 2014; WMO, 2014, and references therein). In contrast, major SSWs are very rare in the Antarctic and conditions favorable for chemical ozone loss persist from mid-May to mid-October with small interannual variations (WMO, 2014, and references therein).

The reactions that destroy ozone in the polar lower stratosphere also require sunlight (e.g., Solomon, 1999, and references therein). Since a large fraction of the polar vortex is typically in darkness in December and January, early-winter ozone loss tends to be small. Consequently, major SSWs in early winter are generally associated with minimal ozone loss through the winters in which they occur. Even among years with comparably extreme SSWs, however, dynamical conditions and ozone loss show large variability. Significant ozone loss has been reported before the major SSWs in late January in 2003 (e.g., Singleton et al., 2005) and 2010 (e.g., Wohltmann et al., 2013). The 2009/10 winter was unusually warm until after mid-December but unusually cold in January, with temperatures below the ice frost point $(\sim 188 \mathrm{~K}$ near $50 \mathrm{hPa})$ on synoptic scales from $\sim 15$ to 25 January. This resulted in the formation of polar stratospheric clouds (PSCs) with solid nitric acid $\left(\mathrm{HNO}_{3}\right)$-containing particles that were large enough to sediment out, leading to denitrification and a consequent slowing of chlorine deactivation after the late January SSW (e.g., Pitts et al., 2011; Dörnbrack et al., 2012; Khosrawi et al., 2011; Wohltmann et al., 2013). Wohltmann et al. (2013) showed that ozone loss continued, albeit at a decreased rate, for more than 1 month after temperatures rose above the chlorine activation threshold. Similarly, in 2002/03 the early winter was unusually cold, but the PSC season was terminated by SSWs starting in late January. Chemical ozone loss, which began in late December before the SSW, was facilitated by the disturbed vortex being exposed to more sunlight than usual in December/January (e.g., Singleton et al., 2005). Several studies have shown evidence for Arctic ozone loss in some winters in late December and January up to $\sim 0.6$ parts per million by volume (ppmv) over shallow layers in the lower stratosphere, but in most winters it is limited to less than $\sim 0.3$ ppmv (e.g., Manney et al., 2003; Rex et al., 2003; Kuttippurath et al., 2010). Kuttippurath et al. (2010) noted significant ozone loss in late December and early January prior to the late-January SSWs in 2006, 2009, and 2010; in 2006 and 2009, the lower stratospheric vortex broke up within 1 to 2 weeks after the SSW, resulting in rapid mixing, chlorine deactivation, and abrupt cessation of ozone loss. Microwave Limb Sounder (MLS) observations during the 2011/12 winter indicate early chlorine activation and suggest a small amount of ozone loss prior to the January 2012 SSW (Bernhard et al., 2012; WMO, 2014).
An exceptionally strong major SSW occurred in early January 2013. The criteria for a major SSW were first met on 6 January 2013, with a large amplification of wave-2 activity (e.g., Goncharenko et al., 2013; Coy and Pawson, 2015); the vortex split in the middle stratosphere within 1-2 days after that time (the timing of the split depends on altitude and on the exact definition of the vortex edge). Coy and Pawson (2015) showed large wave-2 flux into the stratosphere preceding the event and mid-stratospheric temperatures increasing by $40 \mathrm{~K}$ between 1 and 5 January 2013; this upward wave activity flux was associated with Pacific blocking.

Because radiative timescales are long in the lower stratosphere, recovery from prolonged SSWs such as the 2010 and 2013 events is very slow at the levels where polar processing occurs (e.g., Hitchcock and Shepherd, 2013; Hitchcock et al., 2013). Hence, such SSWs typically result in termination of lower stratospheric polar processing. However, the aforementioned studies of the 2009/10 winter indicate that prolonged SSWs starting in late January may be preceded by significant ozone loss.

In this paper, we examine in detail the evolution of the lower stratospheric polar vortex during the 2012/13 winter by characterizing the separated offspring vortices following the split during the January SSW. We combine this information with trace gas data from the MLS instrument on NASA's Aura satellite and information on PSC composition from the Cloud-Aerosol Lidar with Orthogonal Polarization (CALIOP) instrument on NASA's Cloud-Aerosol Lidar and Infrared Pathfinder Satellite Observations (CALIPSO) satellite to show the progression of polar processing in the 2012/13 winter and to estimate chemical ozone loss. We compare polar processing during the 2012/13 winter with that during the other nine Arctic winters observed so far by Aura MLS and seven observed by CALIPSO and detail the conditions associated with the early-January SSW that led to unexpectedly large early-winter ozone loss.

In Sect. 2, we describe the data sets and methods used. Section 3 comprises a detailed discussion of lower stratospheric vortex and temperature evolution in 2012/13 and the implications of that evolution for PSC composition. The evolution of trace gases observed by MLS in relation to the polar vortex is described in Sect. 4. We use trajectory methods to estimate chemical loss and to compare with similar estimates for other winters (Sect. 5). Our conclusions are presented in Sect. 6.

\section{Data and methods}

\subsection{Meteorological data: GMAO analyses}

We use data produced by NASA's Global Modeling and Assimilation Office (GMAO) from their operational Goddard Earth Observing System (GEOS) version 5.9.1 (GEOS5.9.1) analysis and their GEOS version 5.2.0-based Modern 
Era Retrospective Analysis for Research and Applications (MERRA) reanalysis. These data sets are from global atmospheric models that combine 3-D-Var assimilation and incremental analysis update (Bloom et al., 1996) to constrain the analyses. Both MERRA and GEOS-5.9.1 use a hybrid sigma-pressure vertical coordinate with 72 model levels from the surface to $0.01 \mathrm{hPa}$ and have vertical resolutions of $\sim 1 \mathrm{~km}$ in the lower stratosphere. These two data sets have slightly different horizontal resolutions: GEOS5.9 .1 uses a $0.5^{\circ} \times 0.625^{\circ}$ latitude/longitude grid $(361 \times 576$ grid points), while MERRA uses a $0.5^{\circ} \times 0.667^{\circ}$ latitude/longitude grid $(361 \times 540$ grid points $)$. The meteorological fields from these data sets on their model levels are available 8 times per day for GEOS-5.9.1 (00:00, 03:00, 06:00, 09:00, 12:00, 15:00, 18:00, and 21:00UT), and 4 times per day for MERRA (00:00, 06:00, 12:00, and 18:00 UT). Potential vorticity (PV) data from MERRA are available only on a reduced $1^{\circ} \times 1.25^{\circ}$ latitude/longitude grid $(181 \times 288$ grid points) with 42 pressure levels; we interpolate MERRA PV to match the model levels and grid. Rienecker et al. (2008) and Rienecker et al. (2011) provide further details about GEOS and MERRA. The differences between GEOS-5.2.0 and GEOS-5.9.1 are outlined by Molod et al. (2014).

\subsection{MLS and CALIPSO data}

The Earth Observing System (EOS) Aura and CALIPSO satellites are components of the "A-Train" constellation, with $98^{\circ}$ inclination orbits that provide data coverage from $82^{\circ} \mathrm{S}$ to $82^{\circ} \mathrm{N}$ latitude on every orbit.

Aura was launched in July 2004. Aura MLS measures millimeter- and submillimeter-wavelength thermal emission from the limb of Earth's atmosphere. Detailed information on the measurement technique and the Aura MLS instrument is given by Waters et al. (2006). Vertical profiles are measured every $165 \mathrm{~km}$ along the suborbital track and have a horizontal resolution of $\sim 200-500 \mathrm{~km}$ along-track and a footprint of $\sim 3-9 \mathrm{~km}$ across-track. In this study we use version 3 (v3) Aura MLS nitrous oxide $\left(\mathrm{N}_{2} \mathrm{O}\right), \mathrm{HNO}_{3}$, hydrogen chloride $(\mathrm{HCl})$, chlorine monoxide $(\mathrm{ClO})$, and ozone $\left(\mathrm{O}_{3}\right)$ measurements from 2004 through 2014. The quality of these data is described by Livesey et al. (2013). Vertical resolution is about $2.5 \mathrm{~km}$ for $\mathrm{O}_{3}, 3 \mathrm{~km}$ for $\mathrm{HCl}$ and $\mathrm{ClO}, 3-$ $5 \mathrm{~km}$ for $\mathrm{HNO}_{3}$, and $4-6 \mathrm{~km}$ for $\mathrm{N}_{2} \mathrm{O}$ in the lower to middle stratosphere. Single-profile precisions are approximately 0.04-0.1 ppmv, 0.2-0.3 parts per billion by volume (ppbv), $0.1,0.7$, and 13-20 ppbv for $\mathrm{O}_{3}, \mathrm{HCl}, \mathrm{ClO}, \mathrm{HNO}_{3}$, and $\mathrm{N}_{2} \mathrm{O}$, respectively. The v3 MLS data are quality screened as recommended by Livesey et al. (2013), including application of an altitude- and latitude-dependent bias correction for $\mathrm{ClO}$ at 68, 100, and $147 \mathrm{hPa}$.

The CALIPSO satellite was launched in April 2006. CALIOP, the primary instrument on CALIPSO, is a lidar that measures backscatter at wavelengths of 1064 and $532 \mathrm{~nm}$, with the $532 \mathrm{~nm}$ signal separated into orthogonal components parallel and perpendicular to the polarization plane of the outgoing laser beam (Winker et al., 2009; Hunt et al., 2009). Multiple scattering can complicate the analysis of optically thick clouds, but this is not an issue for thin PSCs. On-board data processing is used to average single-shot samples over specific height ranges. The $532 \mathrm{~nm}$ CALIOP calibration is performed over 11 contiguous $5 \mathrm{~km}$ samples in the region 30-34 km, where Rayleigh molecular scattering is assumed. The calibrated data products derived from the three CALIOP channels (Hostetler et al., 2006; Hunt et al., 2009) are attenuated volume backscatter coefficients $\left(\mathrm{km}^{-1} \mathrm{sr}^{-1}\right)$ as a function of altitude.

\subsection{Methods}

\subsubsection{Dynamical characterization of the polar vortex}

Part of our study of the Arctic 2012/13 winter uses diagnostics for assessing meteorological conditions favoring development of PSCs and activation of chlorine. Temperature diagnostics include minimum temperatures, as well as the area ( $\left.A_{\text {PSC }}\right)$ and volume $\left(V_{\mathrm{PSC}}\right)$ of air with temperatures below the threshold ( $T \leq T_{\mathrm{PSC}}$ ) for PSC existence or chlorine activation (note that the subscript "PSC" may be replaced by a specific PSC type). Some recent studies have suggested that liquid PSCs play a dominant role in activating chlorine (e.g., Drdla and Müller, 2012; Wegner et al., 2012; Wohltmann et al., 2013). However, the existence temperatures for solid nitric acid trihydrate (NAT) (Hanson and Mauersberger, 1988) and ice particles remain convenient thresholds for the initiation of chlorine activation processes and are pertinent to the formation of the solid-particle PSCs discussed here; we thus adopt the convention of referring to $T_{\text {NAT }}$ in general discussion related to the possibility of chlorine activation. Polar vortex diagnostics include the area and volume of the polar vortex ( $A_{\text {Vort }}$ and $V_{\text {Vort }}$, respectively), the sunlit area of the polar vortex (sunlit vortex area, SVA), and maximum PV gradients. We calculate these diagnostics from MERRA data, once per day at 12:00 UT, on potential temperature surfaces ranging from 390 to $580 \mathrm{~K}$ (about 14 to $24 \mathrm{~km}^{1}$ ), as in Lawrence et al. (2015). More detailed descriptions of these polar processing diagnostics and their use can be found in Manney et al. (2011) and Lawrence et al. (2015).

Our characterization of the 2012/13 split polar vortex consists of information about the locations, sizes, and shapes of the individual offspring vortices throughout the stratosphere. We adapted algorithms from image processing to identify and track the vortices through time. We define the vortex edge throughout the stratosphere ( 25 vertical levels between 390 and $1800 \mathrm{~K}, \sim 14-54 \mathrm{~km}$ ) based on climatological profiles of scaled PV (sPV, e.g., Dunkerton and Delisi, 1986; Manney et al., 1994b) at the location of the maximum PV

\footnotetext{
${ }^{1}$ In polar winter, the altitude of isentropic surfaces in the lower stratosphere is higher by $1-2 \mathrm{~km}$ in December 2012 than in January 2013.
} 
gradient from MERRA. After identifying closed sPV contours at a single time step, we reject those with equivalent latitude (EqL, the latitude enclosing the same area between it and the pole as a given contour of PV; Butchart and Remsberg, 1986) greater than $82^{\circ}$, corresponding to areas less than $\sim 1 \%$ of a hemisphere. We save the position and extent of each individual vortex in the model grid coordinates and calculate its 2-D moment diagnostics (e.g., Mitchell et al., 2011), its total and sunlit area, and its concentricity with any existing cold regions (e.g., Lawrence et al., 2015). After identifying the vortex regions, a matching procedure philosophically similar to that used by Limbach et al. (2012) is used to track each offspring vortex through time. This tracking is done using the full time resolution available ( 8 times per day for GEOS-5.9.1 and 4 times per day for MERRA) to maximize its accuracy. The multiple vortex characterization procedures and additional applications are described in detail by Lawrence and Manney (2015).

In addition to the diagnostics of polar chemical processing described above, effective diffusivity $\left(K_{\text {eff }}\right)$ is calculated from PV as a diagnostic of mixing. $K_{\text {eff }}$ is expressed as lognormalized equivalent length, that is, the length of a tracer contour with respect to the contour of minimum length that would enclose the same area; high (low) values thus reflect complex (simple) structure in tracer (here PV) contours and indicate strong (weak) mixing (e.g., Nakamura, 1996; Haynes and Shuckburgh, 2000; Allen and Nakamura, 2001). The magnitudes of $K_{\text {eff }}$ values depend strongly on the resolution of the tracer fields used in the calculations, but values from MERRA and GEOS-5.9.1 agree qualitatively; GEOS5.9.1 values are shown here.

To place the 2012/13 winter in the context of other Arctic winters, in addition to comparing with the 35-year MERRA reanalysis, we compare vortex and temperature diagnostics for that winter with those for 2009/10 (1 year during the Aura and CALIPSO missions for which low temperatures, extensive PSC activity, and large early-winter ozone loss before a prolonged SSW have been reported; e.g., Kuttippurath et al., 2010; Pitts et al., 2011) and 2010/11 (the year with the most prolonged cold period and largest Arctic ozone loss on record; e.g., Manney et al., 2011; Hommel et al., 2014; WMO, 2014, and references therein). The interannual variability in the diagnostics shown here is much larger than any biases between different reanalyses (Lawrence et al., 2015); the results are thus robust across different meteorological data sets.

\subsubsection{CALIPSO PSC classification}

The CALIPSO PSC data products are derived from the CALIPSO Lidar Level 1B data products using the PSC detection and composition classification algorithm described in Pitts et al. (2009). The PSC data product contains profiles of PSC presence, composition, optical properties, and meteorological information along CALIPSO orbit tracks re- ported on a $5 \mathrm{~km}$ horizontal by $180 \mathrm{~m}$ vertical grid. PSCs are classified by composition using the CALIPSO PSC algorithm, as described by, e.g., Pitts et al. $(2009,2011)$ and Lambert et al. (2012). The classification is based on the measured CALIOP aerosol depolarization and inverse scattering ratios. CALIPSO PSCs are separated into six composition classes: supercooled ternary solutions (STS), which also include low number densities of NAT particles whose optical signature is masked by the much more numerous STS droplets at low temperatures; three classes of liquid/NAT mixtures, with MIX1, MIX2, and MIX2-enhanced (MIX2E) denoting increasingly higher NAT number density/volume; water ice (ICE); and mountain wave ice (WAVE), a subset of ice PSCs generated through strong cooling associated with orographic waves producing high ice particle number densities $\left(\sim 10 \mathrm{~cm}^{-3}\right)$ but relatively small $(1.0-1.5 \mu \mathrm{m}$ radius $)$ particles (e.g., Fueglistaler et al., 2003). Evaluations of the accuracy of the CALIOP PSC composition classification are provided by Pitts et al. (2013) and Achtert and Tesche (2014).

A relevant parameter for chlorine activation is the total PSC particle surface area, which is primarily that of spherical liquid PSC particles. The lidar particulate backscatter is the integral over the size distribution of particle geometric cross section (which is equal to the surface area/4 for spheres) weighted by the Mie backscatter efficiency (Gobbi, 1995). Thus, the summation of CALIOP particulate backscatter within the vortex is proportional to the total PSC particle surface area (which is primarily determined by liquid particles) in that region.

\subsubsection{MLS data analysis and chemical ozone loss estimates}

$\mathrm{EqL}, \mathrm{sPV}$, and reanalysis temperatures at the MLS locations are obtained from the MLS derived meteorological products (Manney et al., 2007). MLS data are interpolated to isentropic surfaces using temperatures from MERRA. For daily maps and reverse trajectory initialization (see below) the MLS data are gridded at $2^{\circ}$ latitude by $5^{\circ}$ longitude using a weighted average around each grid point of $24 \mathrm{~h}$ of data centered at 12:00 UT. EqL time series are produced using a weighted average of MLS data in EqL, time, and uncertainty (e.g., Manney et al., 1999b, 2007). The vortex average cross sections shown use a single sPV contour of $1.4 \times 10^{-4} \mathrm{~s}^{-1}$ as a proxy for the vortex edge, while more detailed single-level individual vortex calculations use the altitude-dependent sPV profile described above (Sect. 2.3.1). For averages in multiple vortices, the sPV from the derived meteorological products is first used to determine whether the MLS measurement location is within any vortex. Those points that are within a vortex are then marked with the labels for individual regions to identify which of multiple vortices they are inside. Averaging improves MLS precisions to values smaller by a factor of about 10 and 100 for EqL means 
and vortex averages, respectively, over the single-profile precisions listed in Sect. 2.2.

The passive subtraction method using Reverse Trajectory (RT) calculations originated by Manney et al. (1995a, b) has been used in numerous studies of ozone loss in individual winters and to characterize interannual variability in ozone loss during the Upper Atmosphere Research Satellite mission (Manney et al., 2003, and references therein). Here, daily 3-D gridded fields of passively transported $\mathrm{O}_{3}, \mathrm{~N}_{2} \mathrm{O}$, and $\mathrm{HNO}_{3}$ during December 2012 and January 2013 are compared with MLS observations. To the extent that the transport is accurately modeled, the differences between the passively advected and the MLS fields represent the non-transport processes affecting the trace gases - that is, chemical processing and/or, for $\mathrm{HNO}_{3}$, microphysical processes and gravitational settling (denitrification) of PSC particles. The calculations for $\mathrm{N}_{2} \mathrm{O}$ are used to assess the accuracy of the modeled transport as per Manney et al. (1995b). The trajectory runs for the RT ozone loss calculations are done using an adapted version of the Lagrangian Trajectory Diagnostic code described by Livesey (2013), which advects parcels using a fourth-order Runge-Kutta scheme. We use winds, temperatures, and diabatic heating rates from MERRA and perform backward trajectories for days in December 2012 and January 2013. Parcels are initialized on 10 isentropic surfaces from 390 to $660 \mathrm{~K}(\sim 14-27 \mathrm{~km})$ on a $2^{\circ} \times 5^{\circ}$ Northern Hemisphere latitude/longitude grid. Although every $15 \mathrm{~min}$ integration time step is saved, we use only the 12:00 UT locations to determine the estimates of ozone loss. Passive ozone on the initial grid is obtained by initializing the back trajectories on a common date. For example, trajectories on each day from 8 December through 1 January were initialized with gridded MLS data on 8 December to estimate chemical loss on each day of that period. While Morris et al. (1995) found that trajectory errors often increased substantially after about 15 days, Manney et al. (2003) found that RT calculations similar to those done here were reasonably accurate using trajectories 20-40 days long, depending on the meteorological situation. To obtain estimates for early December through January, while limiting the duration of back trajectories to no more than 1 month, the parcels run back from January days are initialized using the results for 1 January from the calculation initialized with MLS data on 8 December. Sensitivity tests for the 8 December 2012 to 31 January 2013 period using trajectories reinitialized every 10-12 days did not show significantly different results than those presented with a single reinitialization near the middle of the period. Frequent reinitialization also becomes problematic because air from outside the initialization domain advected into the region of interest can result in growing areas of missing data.

A different Lagrangian method, the Match-based approach of Livesey et al. (2015), has also been used to estimate December through January $\mathrm{O}_{3}$ loss in 2004/05 through 2012/13. The trajectory calculations, or "MLS Lagrangian Trajectory Diagnostics", are described by Livesey (2013) and the MLS
Match method is discussed in detail by Livesey et al. (2015). Briefly, the Lagrangian Trajectory Diagnostics are computed by launching a cluster of parcels from each MLS measurement location and time. Air masses sampled by MLS on multiple orbits are identified using these Lagrangian Trajectory Diagnostics, and the differences between ozone at the initial time and subsequent measurements are used to calculate chemical ozone loss rates in a procedure similar to that developed by von der Gathen et al. (1995) and Rex et al. (1998, 1999, 2002). Several criteria - including SPV greater than $1.4 \times 10^{-4} \mathrm{~s}^{-1}$ (indicating vortex air), approximate conservation of sPV, and limited dispersion among the cluster of parcels launched at each location - provide information to screen the matches. Calculations are done using a "standard" $(25 \%)$ and "stricter" (10\%) limit on the divergence in SPV between matched observations (Livesey et al., 2015). Nonzero changes in $\mathrm{N}_{2} \mathrm{O}$ between matched observations are assumed to arise from errors in modeled transport and are used to estimate the effect of those errors on $\mathrm{O}_{3}$ loss uncertainties. In contrast to the sonde-based Match studies with hundreds of matches over the course of a winter, the MLS sampling provides thousands of matches each day.

\section{Polar vortex, temperature, and PSC evolution in 2012/13}

Figure 1 gives a qualitative overview of the vortex and temperature evolution during the 2012/13 Arctic winter (an animation covering the full winter is available as a Supplement). A near-split of the lower stratospheric vortex at the beginning of December was associated with a brief temperature increase. Another vortex split in the lower stratosphere was seen around 10 December. Despite these significant vortex disturbances, a large, deep region of temperatures below $T_{\text {NAT }}$ persisted through December. By 1 January, a separate cold region developed at high altitude (from about 650 to above $800 \mathrm{~K}$ ) and merged with the large lower stratospheric cold region that extended below $390 \mathrm{~K}$. The vortex was often elongated, and the cold region was typically shifted towards the side extending over North America, especially in the period immediately preceding the early January split associated with the major SSW, when the vortex was stretched into two (connected) lobes such that the air in the core of each circulated within that individual lobe. By 4 January, the cold region was much smaller, though still extending through the depth of the lower stratosphere. During 4 through 6 January the vortex continued to elongate, and temperatures increased above $T_{\mathrm{NAT}}$ (Supplement). On 7 January (shown in Fig. 1), a small region of temperatures below $T_{\mathrm{NAT}}$ reappeared at 600 to $750 \mathrm{~K}$. At this time, the vortex was beginning to split throughout the vertical domain shown.

By 9 January, the vortex was completely split at all levels shown, and no temperatures below $T_{\mathrm{NAT}}$ remained. Both the simultaneous splitting over a deep altitude region 

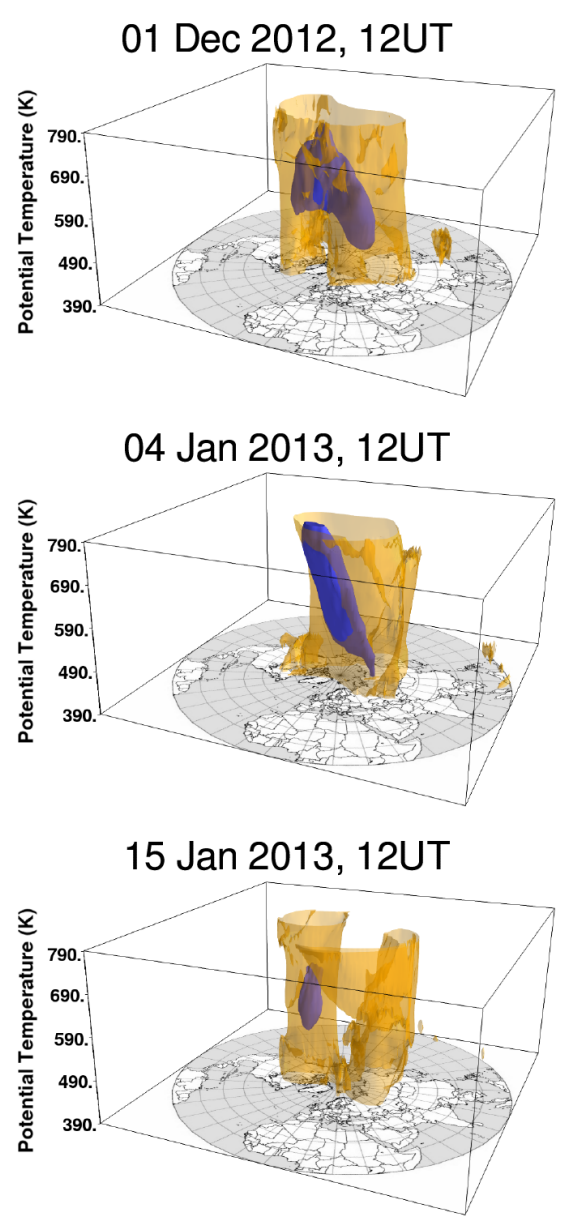
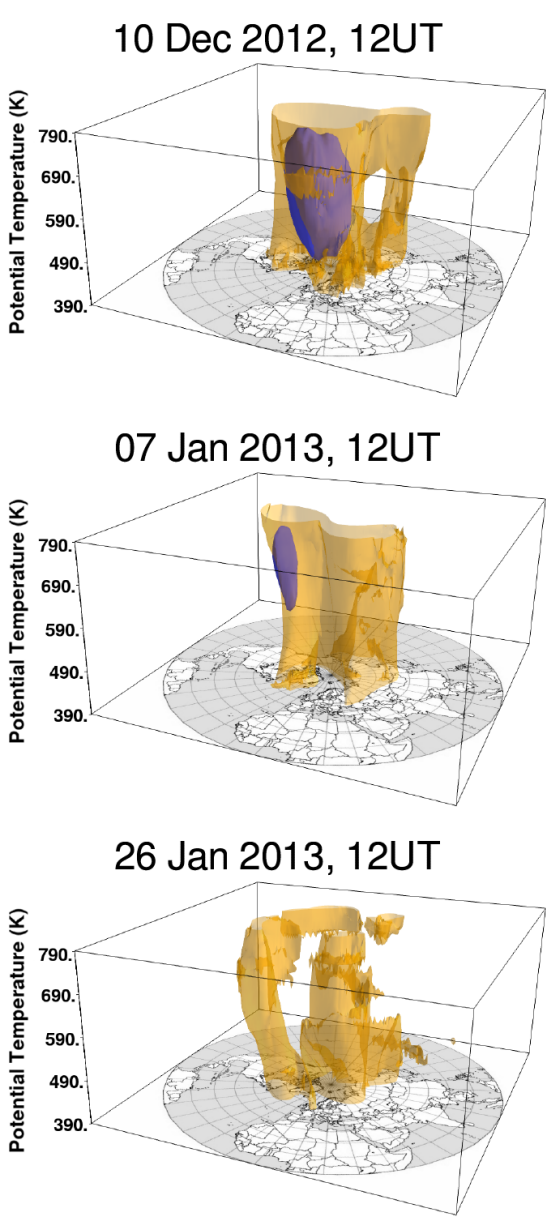
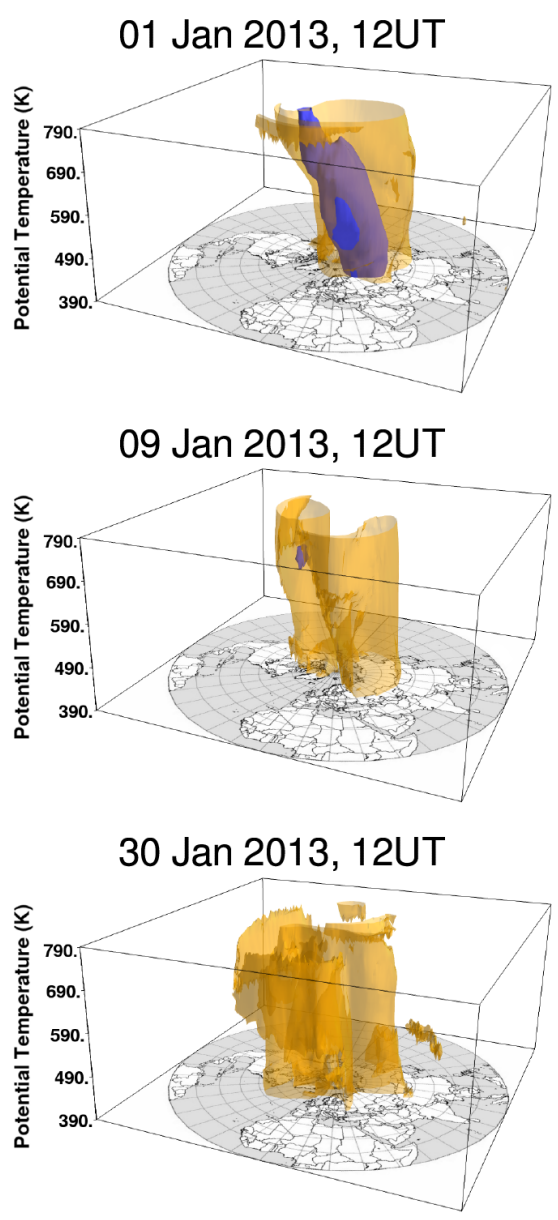

Figure 1. Isosurfaces of $T_{\mathrm{NAT}}$ (blue) and the vortex edge (orange). The vortex edge is defined by the altitude-dependent sPV profile described in Sect. 2.3.1. An animation covering the 2012/13 winter is available as a Supplement.

and the unequal split into smaller "Canadian" and larger "Siberian" offspring vortices with positions similar to those in 2012/13 are common characteristics of vortex-split SSWs (e.g., Matthewman et al., 2009). The two offspring vortices continued to evolve and remained well-defined throughout the vertical domain until the last few days of January, with a brief reappearance of temperatures below the activation threshold between 14 and 18 January (Fig. 1 shows 15 January) in the Canadian vortex. On 26 January, the vortices began moving back together, and they merged by 30 January. We describe below the impact of this temperature and vortex evolution on the potential for polar chemical processing and $\mathrm{O}_{3}$ loss.

Figure 2 shows the evolution of lower stratospheric temperatures at $490 \mathrm{~K}(\sim 55 \mathrm{hPa}, \sim 20-21 \mathrm{~km})$ from the 35-year MERRA reanalysis, with 2009/10, 2010/11, and 2012/13 highlighted. Minimum temperatures (top panel) were unusually low during late November and December 2012 (orange line) but within the range seen in the past 35 years; temperatures below the ice PSC existence threshold $\left(T \leq T_{\text {Ice }}\right)$ were seen continuously at this level from about 5 Decem- ber through 1 January. The brief warming associated with the early December lower stratospheric vortex split resulted in temperatures rising near $T_{\mathrm{NAT}}$ at $490 \mathrm{~K}$ and above it at lower levels (not shown). The $490 \mathrm{~K}$ temperatures in December 2012 were much lower than those in December 2009 (which was unusually warm; e.g., Dörnbrack et al., 2012) and more persistently low than those in December 2011. Heat fluxes at $100 \mathrm{hPa}$ from approximately 5 to 20 December 2013 were exceptionally low (even negative on some days) (e.g., Coy and Pawson, 2015, also see plots available at http: //acd-ext.gsfc.nasa.gov/Data_services/met/ann_data.html), a condition often associated with less wave activity and lower temperatures.

Temperatures at $490 \mathrm{~K}$ in 2012/13 began rising rapidly on 31 December, exceeding $T_{\mathrm{NAT}}$ on 5 January 2013 . Temperatures dropped to just below $T_{\mathrm{NAT}}$ around 13 January, before rising abruptly again starting around 19 January. Minimum temperatures in early January 2013 exceeded $T_{\mathrm{NAT}}$ slightly before the onset of the major SSW (that is, the date when the criteria for a major SSW were first met). In contrast, in late January 2010, despite a rapid temperature increase following 


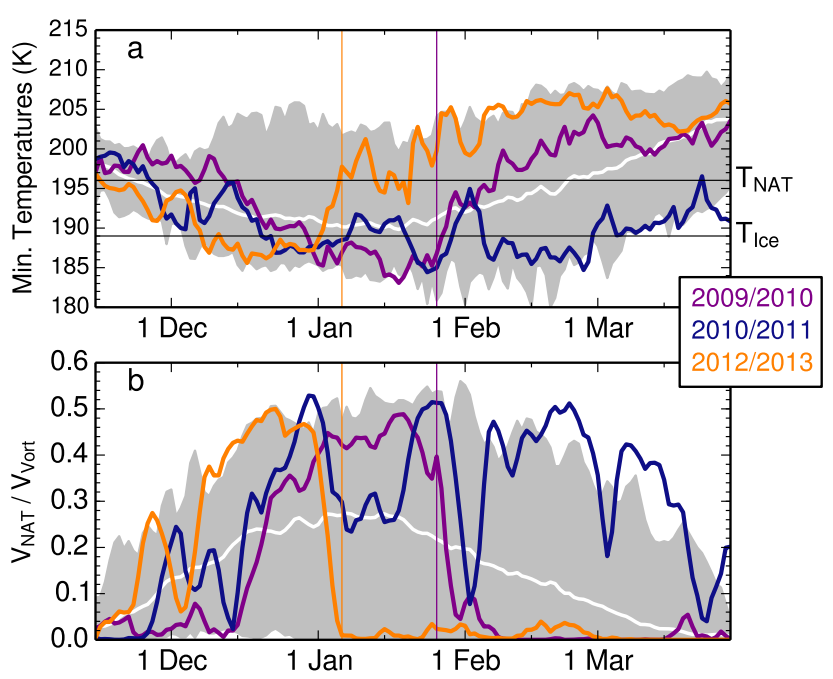

Figure 2. Time series of (a) minimum temperatures poleward of $40^{\circ} \mathrm{N}$ at $490 \mathrm{~K}$ and (b) $V_{\mathrm{NAT}} / V_{\text {Vort }}$ (see text) from MERRA reanalysis. Individual lines show 2009/10 (purple), 2010/11 (blue), and 2012/13 (orange). Envelope shows the remaining years from $1979 / 80$ through 2013/14. Thin vertical lines indicate the dates when the major SSW criteria were met in 2010 (purple) and 2013 (orange). Thin black horizontal lines in (a) indicate the NAT and ice PSC thresholds.

the onset of the SSW, temperatures remained below $T_{\mathrm{NAT}}$ for about 1 week before gradually rising above that threshold. The late-January 2010 SSW was a vortex displacement event, as opposed to a vortex split in 2013 (e.g., Dörnbrack et al., 2012; Coy and Pawson, 2015); previous studies have indicated that vortex-split SSWs tend to be more barotropic in the sense of occurring simultaneously over a wide range of altitudes rather than earlier at higher levels (e.g., Matthewman et al., 2009).

The fraction of the vortex volume with $T \leq T_{\mathrm{NAT}}$, $V_{\mathrm{NAT}} / V_{\text {Vort }}$, in 2012/13 (Fig. 2b) was as large as - sometimes slightly larger than - that previously observed in the Arctic both in late November and, after a brief warming, through the rest of December. The abrupt drop of $V_{\mathrm{NAT}} / V_{\mathrm{Vort}}$ to near 0 indicates the concurrent disappearance of $T \leq T_{\mathrm{NAT}}$ at all altitudes. This is shown explicitly in Fig. 3a: a large area of $T \leq T_{\mathrm{NAT}}$ formed in late November, with a brief warming in early December; the large area of $T \leq T_{\mathrm{NAT}}$ extended from about 420 to $700 \mathrm{~K}$ from about 5 December through the beginning of January, then dropped to 0 by 6 January at all levels. There was a brief dip to $T \leq T_{\mathrm{NAT}}$ for a few days in mid-January 2013 at levels between $\sim 500$ and $600 \mathrm{~K}$. The contrast with the warming associated with the 2010 SSW is seen clearly in the overlaid purple line on Fig. 3a, which drops rapidly above about $520 \mathrm{~K}$ (though not as rapidly as in 2013 and after, rather than before, the SSW onset) but much more slowly below that level. Both the 2009/10 and 2010/11 Arctic winters were notable for an unusually deep region of low temperatures (e.g., Manney et al., 2011; Dörnbrack et al.,
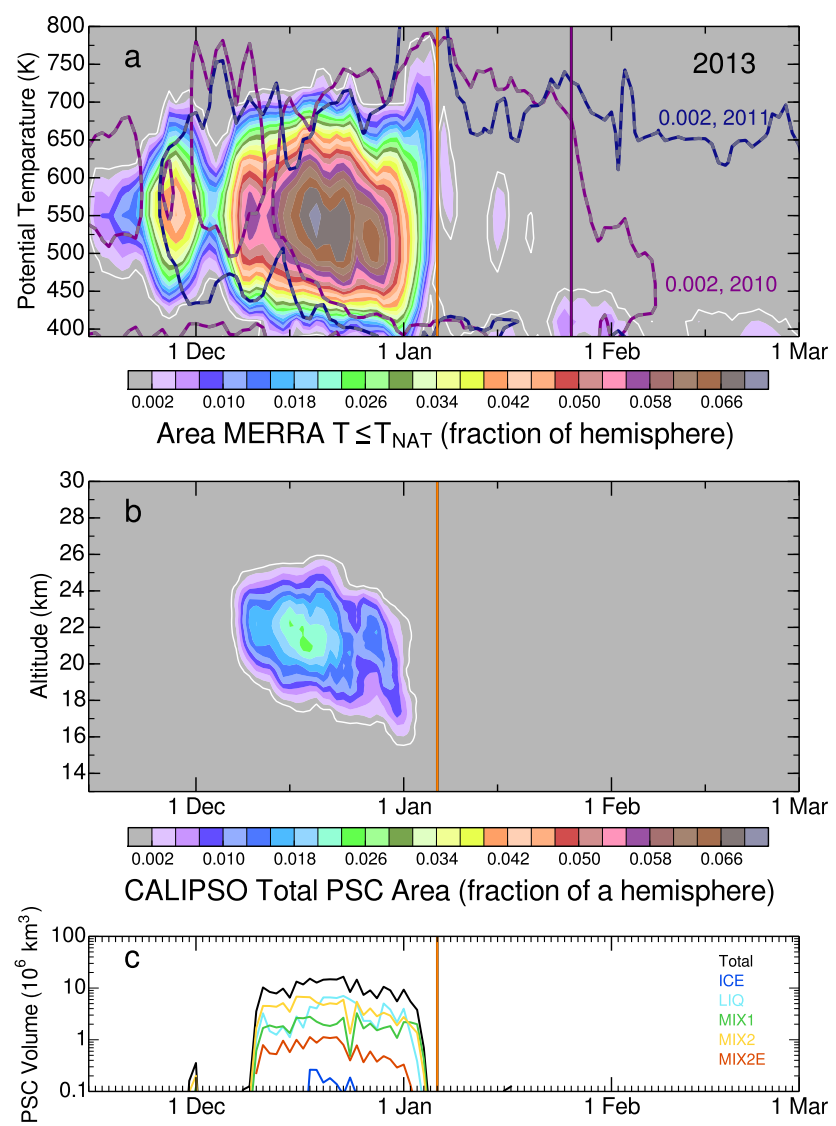

Figure 3. (a) Time series of the area poleward of $30^{\circ} \mathrm{N}$ with $T \leq T_{\text {NAT }}$ as a function of potential temperature in $2012 / 13$ from MERRA (color fill; the white contour shows a value of 0.001 , indicating a very small nonzero value); area is expressed as fraction of a hemisphere, with a color bar range from 0 to 0.07 . The overlaid purple and blue contours show the 0.002 contour (which is at the boundary between grey and lavender in 2012/13) in 2009/10 and 2010/11, respectively; purple and orange vertical lines show the beginning dates of the SSWs in 2010 and 2013, respectively. (b) Time series of CALIPSO total PSC area; format is as in (a) but with only 2012/13 values. (c) Time series of the total volume of different types of PSCs observed by CALIPSO in 2012/13 (see text).

2012). Figure $3 a$ shows that the cold region in early winter 2012/13 was as deep as that in those two previous winters; this, along with unusually low temperatures during most of December, resulted in the record high $V_{\mathrm{NAT}} / V_{\text {Vort }}$.

Figure $3 \mathrm{~b}$ shows the total area of PSCs detected by CALIPSO. Consistent with the very low temperatures in the last 3 weeks of December, an extensive area of PSCs was seen from about 17 to $25 \mathrm{~km}$ (approximately 430 to $600 \mathrm{~K}$ ). The volume of various PSC types (Fig. 3c) shows, in addition to a large volume of liquid PSCs, substantial regions of MIX1, MIX2, and MIX2E PSCs during approximately the last 3 weeks of December, as well as a small region of ice PSCs in mid-December associated with orographic wave activity near Novaya Zemlya (in the Arctic Ocean north 


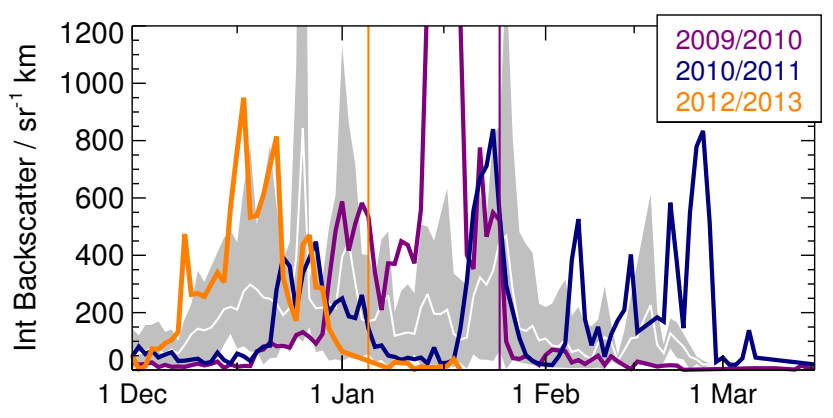

Figure 4. Vortex-integrated CALIPSO backscatter $\left(\mathrm{sr}^{-1} \mathrm{~km}\right)$ at $490 \mathrm{~K}$, proportional to the total liquid particle surface area within the vortex, as a function of day in 2012/13 (orange), 2010/11 (blue), and 2009/10 (purple) compared with the range (grey shading) and average (white line) for the other years in 2006/07 through 2013/14.

of Russia). The widespread presence of these liquid/NAT mixtures, which include large $\mathrm{HNO}_{3}$-containing particles, suggests conditions favorable for sedimentation of PSCs and hence denitrification.

As seen in Fig. 4, the vortex-integrated particulate backscatter at $490 \mathrm{~K}$ (near $21 \mathrm{~km}$ in December 2012) in December 2012 was as large as or larger than that in the other years (2006 through 2013) observed by CALIPSO and much larger than the average values during December. The patterns shown here are consistent with the evolution of $V_{\mathrm{NAT}} / V_{\mathrm{Vort}}$ (Fig. 2b). None of the other winters observed had such a persistent period of large vortex-integrated backscatter in December: values in December 2011 define the envelope for the years not shown individually between about 5 and 20 December, with much less persistent high values in the other years; the large off-scale peak in January 2010 was when CALIPSO observed synoptic-scale ice PSC activity in the exceptionally cold period before the late-January 2010 SSW (e.g., Pitts et al., 2011; Dörnbrack et al., 2012). Since the vortex-integrated backscatter is a proxy for the total particle surface area, the pervasive high values in December 2012 lead to the expectation of early chlorine activation.

The impact of the temperature evolution described above on the polar processing potential over the 2012/13 winter in relation to other years is shown in Fig. 5. The total number of days in a winter with temperatures below $T_{\mathrm{NAT}}$ integrated from 390 to $550 \mathrm{~K}$ (Fig. 5a) is closely correlated with the timing of SSWs: major SSWs in 1984/85, 1998/99, and 2001/02 began in December (e.g., Randel and Boville, 1987; Manney et al., 1999a; Naujokat et al., 2002), and the onset of the major SSW in 2003/04 was in the first few days of January (e.g., Manney et al., 2005). The total number of cold days in 2012/13 was slightly larger than that in 2003/04 (when the SSW was at a similar time) because of the unusually deep cold region in 2012/13. Winter mean (1 December through 15 April) $V_{\mathrm{NAT}} / V_{\text {Vort }}$ (Fig. 5b) shows a considerably larger activation potential in 2012/13 than in the previous winters with very early SSWs, reflecting the persistent deep cold re- gion in December 2012. Winter mean $V_{\mathrm{NAT}} / V_{\text {Vort }}$ was nearly as large as that in 2008/09 and 2009/10, when the major SSWs were 18-20 days later.

Polar vortex characteristics relevant to chemical processing are shown in Fig. 6. Figure 6a shows the daily maximum $\mathrm{PV}$ gradients calculated as a function of EqL, a measure of the strength of the polar vortex as a transport barrier (e.g., Manney et al., 1994a, 2011; Lawrence et al., 2015). Although the major SSW commenced and the vortex split in early January 2013 (with concurrent reversal of the high latitude zonal mean winds), PV gradients remained near the climatological average until the end of January then dropped rapidly to very low values, indicating that the vortex was no longer well defined. Zonal mean winds (not shown) began to increase in February when the reforming vortex was relatively symmetric and pole-centered. The vortex recovered strongly in the middle and upper stratosphere by mid-February, but very weak PV gradients along the edge of the reformed vortex in the lower stratosphere indicate that it was an insignificant transport barrier there at that time. The 2010 SSW, in contrast, did not result in a complete breakdown of the lower stratospheric vortex (previously noted by, e.g., Dörnbrack et al., 2012).

Figure $6 \mathrm{~b}$ and $\mathrm{c}$ show daily time series of SVA (the portion of the vortex that is equatorward of the latitude of polar night), indicating where, combined with low temperatures, there is potential for chlorine-catalyzed $\mathrm{O}_{3}$ loss. Figure $6 \mathrm{~b}$ shows SVA expressed as a fraction of the vortex area. There were periods in December in both 2010 and 2012 when the vortex received much more sunlight than usual. In both winters, these periods were associated with very disturbed conditions in which the vortex was highly elongated and split or nearly split in the lower stratosphere (e.g., Cohen et al., 2010, and Wang and Chen, 2010, discuss lower stratospheric vortex disturbances in December 2009); in December 2010, however, these periods were unusually warm, with no PSC activity (e.g., Dörnbrack et al., 2012). In addition to those substantial periods in December 2012, most of the vortex (or, more precisely, the offspring vortices following the split) sat in regions that experienced sunlight throughout January 2013. Figure 6c shows SVA and total vortex area expressed as a percentage of the hemisphere, demonstrating that not only was the sunlit vortex area unusually large in 2012/13 but the total vortex size was also exceptionally large during December 2012 .

Another diagnostic examined is the vortex-temperature concentricity, calculated by determining the degree to which the centroids of the vortex and cold regions are co-located (Lawrence et al., 2015). These calculations (not shown) indicate a fairly typical degree of concentricity in much of December 2012 prior to the SSW but with unusual excursions to very low values in the first approximately 10 days of December and the first several days of January immediately before the SSW. Low vortex-temperature concentricity is associated with a cold region near the vortex edge that 

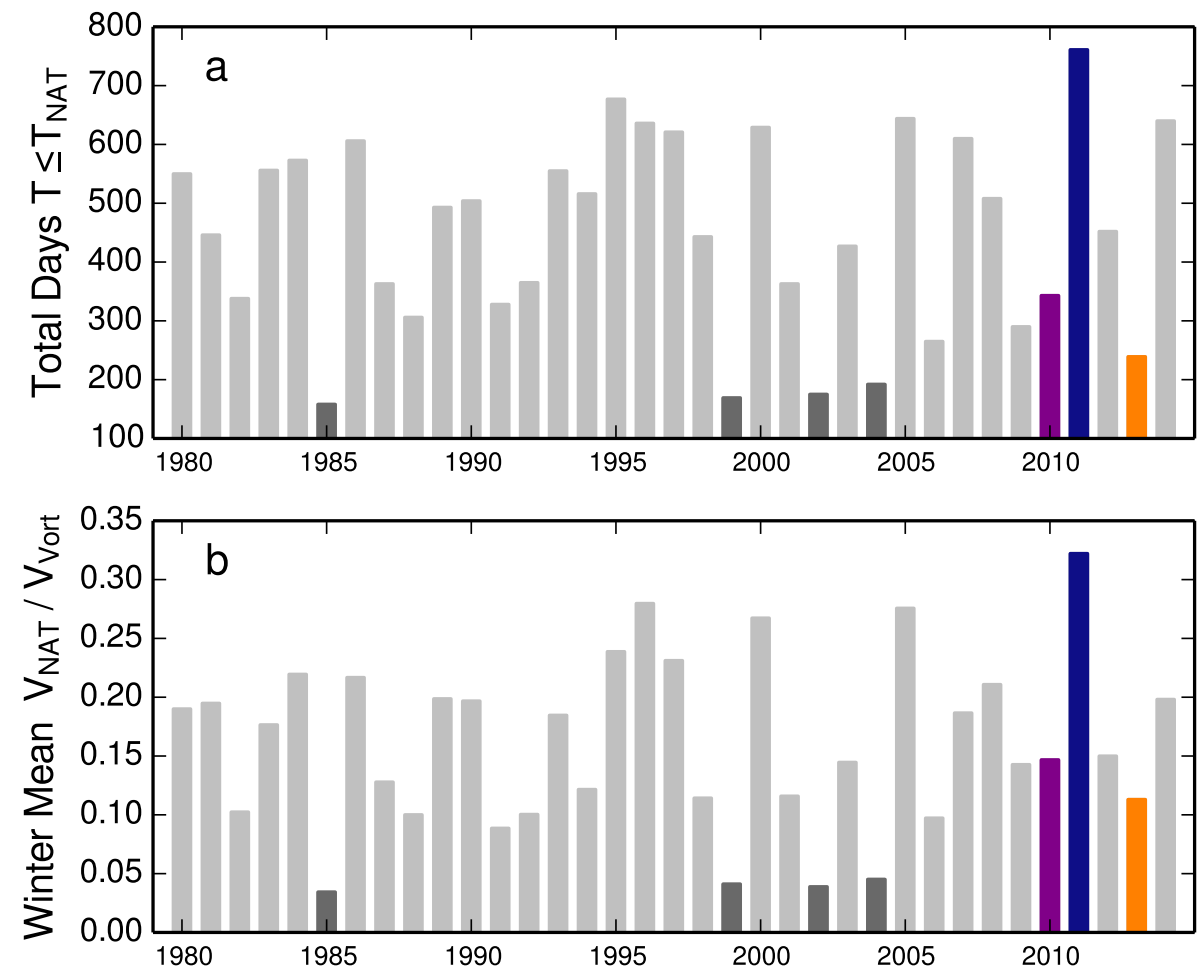

Figure 5. Summary temperature information from MERRA reanalysis for the past 35 Arctic winters: (a) the number of days below $T_{\mathrm{NAT}}$ summed over isentropic levels from 390 to $550 \mathrm{~K}$; (b) winter mean $V_{\mathrm{NAT}} / V_{\text {Vort }}$ calculated from 1 December through 15 April. Years $2009 / 10$, 2010/11, and 2012/13 are highlighted in purple, blue, and orange, respectively. Dark grey bars indicate other winters with major SSWs in December or early January. Year numbers are for the January of each winter.

experiences stronger winds, thus facilitating the processing of more air through regions with PSCs; previous studies have shown that this results in more extensive chlorine activation (Santee et al., 2003, and references therein).

\section{Lower stratospheric trace gas evolution in 2012/13}

\subsection{Overview and average trace gas evolution}

In the following subsections, we look at the effects of the vortex, temperature, and PSC evolution described above on MLS-observed trace gas distributions in the 2012/13 winter. Figure 7 shows maps of MLS trace gases on selected days during January 2013. The persistence of strong $\mathrm{N}_{2} \mathrm{O}$ gradients across the vortex edge demonstrates clearly that air in the offspring vortices remained well confined through January 2013. When the vortices merged at the end of January, PV gradients weakened, and some mixing was evident (e.g., in the 0 to $45^{\circ} \mathrm{E}$ sector on 31 January), but the well-defined region of low $\mathrm{N}_{2} \mathrm{O}$ values indicates that most of the air in the reunified vortex remained fairly isolated.

Consistent with the large region of temperatures below $T_{\text {NAT }}$ on 1 January, $\mathrm{HNO}_{3}$ values were very low through much of the vortex. While vortex $\mathrm{HNO}_{3}$ did increase slightly after temperatures rose above the PSC threshold on $\sim 5$ Jan- uary, it remained much lower than is typical in warm Arctic winters in the confined region of each offspring vortex, suggesting that substantial denitrification had occurred. Chlorine was strongly activated on 1 January, and persistent welldefined regions of confined low $\mathrm{HCl}$ were seen in the offspring vortices through January. Throughout the period after the vortex split, the offspring vortices were mostly in regions that receive sunlight, and thus $\mathrm{ClO}$ remained elevated within them. Some chlorine activation was still apparent when the vortices merged at the end of January. The unusually low $\mathrm{HNO}_{3}$ values may have inhibited reformation of $\mathrm{ClONO}_{2}$, the typical pathway for rapid chlorine deactivation in the Arctic (Douglass et al., 1995; Santee et al., 2008, and references therein).

On 1 January, ozone values were high through most of the vortex. The values in the offspring vortices decreased throughout January, consistent with chlorinecatalyzed ozone loss in both offspring vortices. It is not obvious from the ozone fields themselves whether the low values inside the merged vortex originated from the offspring vortices or from air drawn in from low latitudes; low $\mathrm{N}_{2} \mathrm{O}$ values (characteristic of the vortex) in the same region suggest the former.

Figures 8 and 9 give a more comprehensive view of the trace gas evolution in the 2012/13 winter, showing EqL/time 

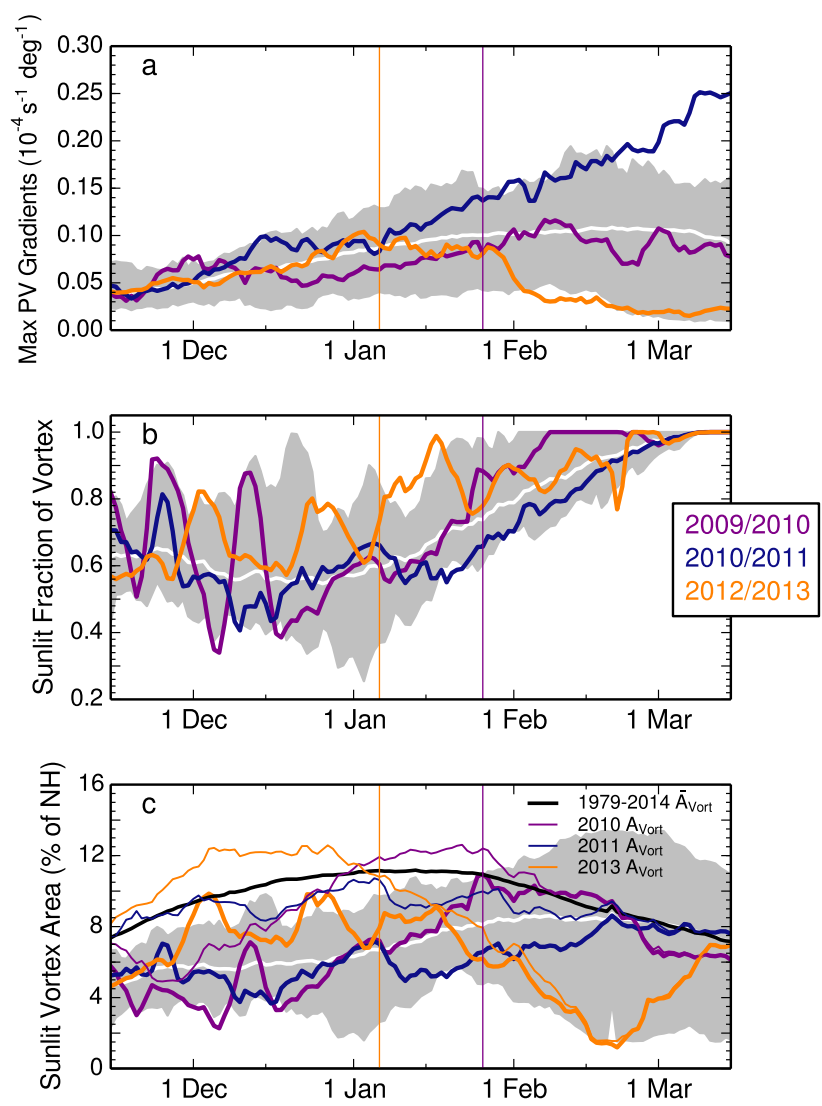

Figure 6. Time series from MERRA reanalysis at $490 \mathrm{~K}$ of (a) potential vorticity (PV) gradients as a function of EqL $\left(10^{-4} \mathrm{~s}^{-1} \mathrm{deg}^{-1}\right)$ and sunlit vortex area (SVA) expressed as (b) a fraction of the total vortex area and (c) a fraction of the hemisphere, with total vortex area shown as thin lines. Shading and line colors are as in Fig. 2.

plots of $K_{\text {eff }}$ and MLS trace gases at $490 \mathrm{~K}$ and potential temperature/time sections of vortex-averaged (over both offspring vortices) trace gases, respectively. Low $K_{\text {eff values co- }}$ incident with strong PV gradients (Fig. 8a) confirm that the vortices represented a strong transport barrier through January, with a rapidly shrinking isolated region in early February and complete dissipation of the vortex as a significant transport barrier by late February. The continuing decline of $\mathrm{N}_{2} \mathrm{O}$ into early February (Fig. 8b), coupled with strong gradients across the vortex edge, confirms the isolation of the vortex and indicates that descent continued into early February. Low values of and strong gradients in $\mathrm{N}_{2} \mathrm{O}$ through late February indicate the persistence of a well-defined vortex region. $\mathrm{HNO}_{3}$ values also remained low through mid-February in most of the vortex region (Fig. 8c). Low $\mathrm{HCl}$ and high $\mathrm{ClO}$ values (Fig. 8d and e) were present until early February, when a rapid increase in $\mathrm{HCl}$ and decrease in $\mathrm{ClO}$ indicates deactivation. The rapid decrease in ozone in late December through January, when $K_{\text {eff, }}$ PV gradients (see Fig. 6a and overlaid contours in Fig. 8), and $\mathrm{N}_{2} \mathrm{O}$ all indicate that the vor- tex was still isolated and confined descent continued, implies chemical ozone destruction. Because descent brings down air rich in ozone, the amount of chemical ozone destruction likely exceeded the observed decrease in ozone abundances.

Figure 9a shows a slight transient increase in $\mathrm{N}_{2} \mathrm{O}$ below $600 \mathrm{~K}$ at the time of the vortex split ( $\sim 8$ January), suggesting a small amount of associated mixing. The downward tilt of the contours, however, continues through the time when the offspring vortices begin to merge, after which the upward tilt of $\mathrm{N}_{2} \mathrm{O}$ contours at the lowest levels and sharp increase at $\sim 500-650 \mathrm{~K}$ indicate enhanced mixing.

Low vortex-averaged $\mathrm{HNO}_{3}$ (Fig. 9b) persisted from about 440 to $580 \mathrm{~K}$ through January, after PSCs had evaporated (Fig. 3), with the altitude of the lowest values decreasing gradually, from about 530 to $480 \mathrm{~K}$, from late December through mid-January. The episodic higher values near $420 \mathrm{~K}$ in late December and early January suggest renitrification as PSC particles fell to levels where there was a much smaller region of $T \leq T_{\mathrm{NAT}}$ (see Fig. 3) and evaporated/sublimated. The persistence of low vortex $\mathrm{HNO}_{3}$ after temperatures had risen and the evidence of renitrification are similar to the behavior seen in the very cold period before the SSW in late January 2010 (Khosrawi et al., 2011). Figure 10 provides further evidence for the occurrence of denitrification/renitrification: on 16 December, MLS measurements along an orbit track show very low gas-phase $\mathrm{HNO}_{3}$ values co-located with a region of CALIPSO PSC observations composed largely of MIX1 and MIX2, with some MIX2E. On 28 December, a region of low $\mathrm{HNO}_{3}$ remained although no PSCs were observed, and an underlying enhancement of $\mathrm{HNO}_{3}$ shows the signature of renitrification. An estimate of particle size and number density using the method described by Lambert et al. (2012) indicates the presence of numerous large particles (radii $>6 \mu \mathrm{m}$ ) on 16 December. Figure 3 (bottom panel) shows that liquid/NAT mixture PSCs were abundant throughout the cold period in December 2012, implying that the processes exemplified in Fig. 10 were widespread during this period.

The region of activated chlorine (low $\mathrm{HCl}$, high $\mathrm{ClO}$ in Fig. 9c and d) extended above $600 \mathrm{~K}$ through mid-January. $\mathrm{HCl}$ gradually increased at the highest levels shortly after the vortex split; evidence of somewhat more mixing at these levels than at lower levels is apparent in the vortex-averaged $\mathrm{N}_{2} \mathrm{O}$ (Fig. 9a). Increasing $\mathrm{HCl}$ values extended to lower and lower levels through February. The maxima in $\mathrm{ClO}$ around 20 December and from about 5 through 20 January were concurrent with maxima in SVA (Fig. 6). The SVA as a fraction of the vortex reached a maximum of 1.0 after $\mathrm{HCl}$ began to rise; consequently, maximum $\mathrm{ClO}$ values were observed after deactivation had already begun because more of the active chlorine was converted to $\mathrm{ClO}$ even though the absolute amount was decreasing. Note that the partitioning of active chlorine also shifts towards $\mathrm{ClO}$ at higher temperatures (e.g., Santee et al., 2010, and references therein), which may have contributed to these variations. The low abundances of $\mathrm{HNO}_{3}$ 

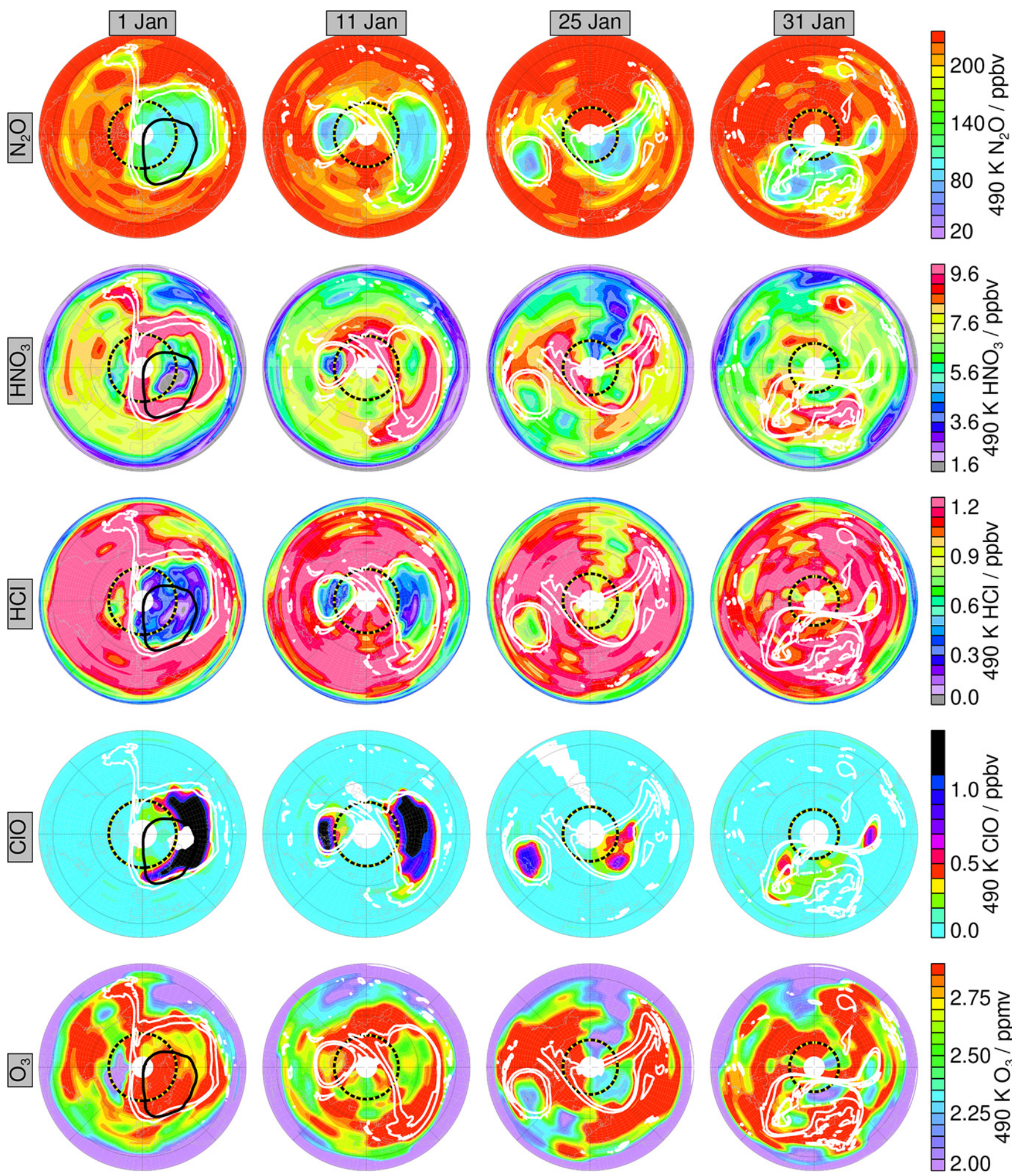

Figure 7. Maps of MLS trace gases on the $490 \mathrm{~K}$ isentropic surface for selected days in January 2013, top to bottom: $\mathrm{N}_{2} \mathrm{O}$ (color bar range 20 to $236 \mathrm{ppbv}$ ), $\mathrm{HNO}_{3}$ (color bar range 1.6 to $10 \mathrm{ppbv}$ ), $\mathrm{HCl}$ (color bar range 0 to $1.26 \mathrm{ppbv}$ ), $\mathrm{ClO}$ (color bar range 0 to $1.4 \mathrm{ppbv}$ ), and $\mathrm{O}_{3}$ (color bar range 2.0 to $2.9 \mathrm{ppmv}$ ). Yellow/black dashed line shows the latitude of polar night. White overlays are sPV contours of 1.2 and $1.6 \times 10^{-4} \mathrm{~s}^{-1}$, representative of the vortex edge. The thick black contour (visible only on 1 January) outlines the region with temperatures less than $196 \mathrm{~K}$, the approximate chlorine activation threshold. Projection is orthographic, with $0^{\circ}$ longitude at the bottom and $90^{\circ} \mathrm{E}$ to the right. Thin black circles show 30 and $60^{\circ} \mathrm{N}$ latitudes. 

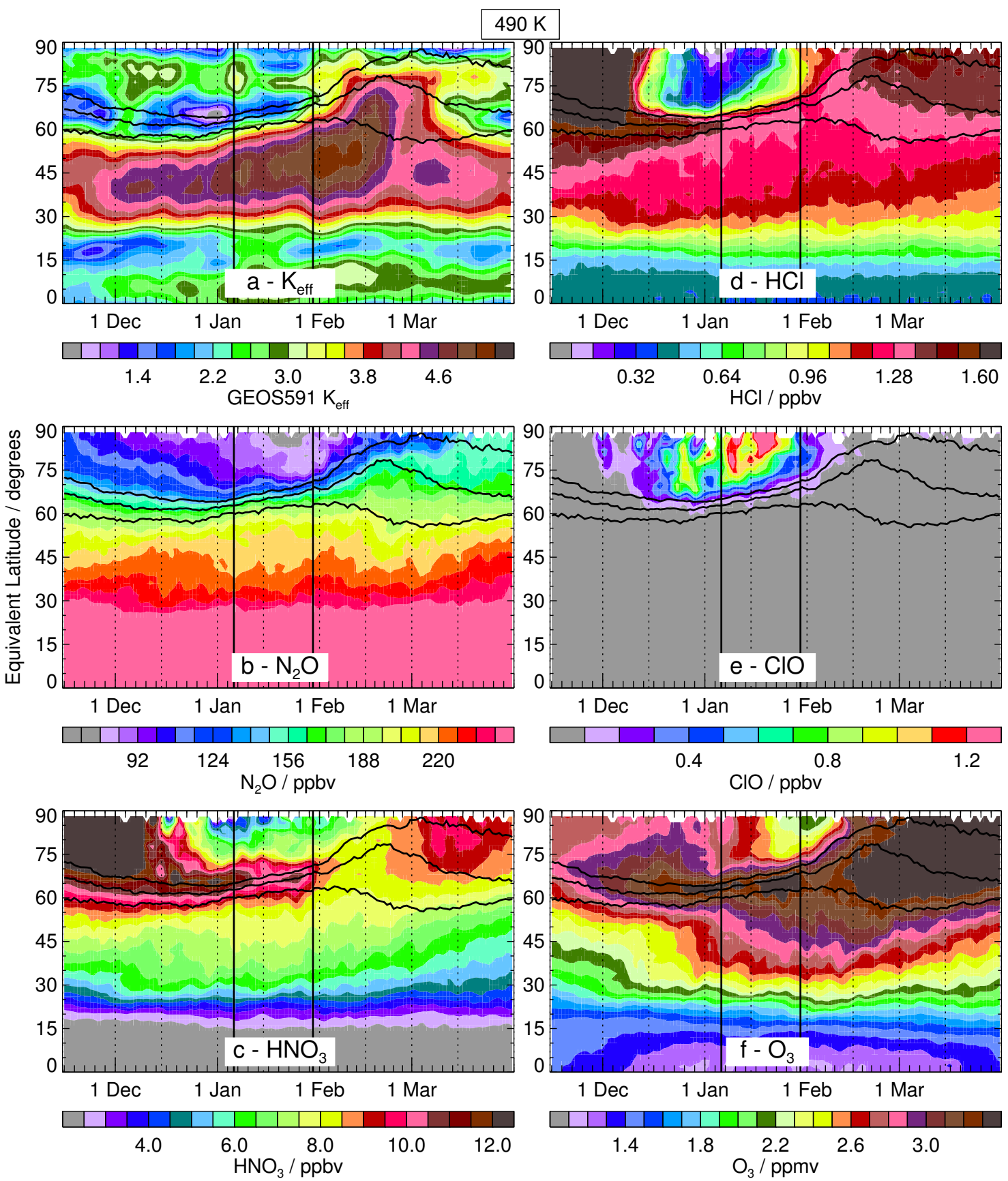

Figure 8. Equivalent latitude/time series at $490 \mathrm{~K}$ of (a) effective diffusivity from GEOS-5.9.1 (color bar range 0.6 to 5.4 , expressed as log-normalized equivalent length; low values indicate transport barriers and high values regions of enhanced mixing) and MLS (b) $\mathrm{N}_{2} \mathrm{O}$ (color bar range 60 to $252 \mathrm{ppbv}$ ), (c) $\mathrm{HNO}_{3}$ (color bar range 2.0 to $12.5 \mathrm{ppbv}$ ), (d) $\mathrm{HCl}$ (color bar range 0 to $1.68 \mathrm{ppbv}$ ), (e) $\mathrm{ClO}$ (color bar range 0 to $1.3 \mathrm{ppbv}$ ), and (f) $\mathrm{O}_{3}$ (color bar range 1.0 to $3.4 \mathrm{ppmv}$ ). Black contours show $\mathrm{sPV}$ values of $1.2,1.4$, and $1.6 \times 10^{-4} \mathrm{~s}^{-1}$ in the vortex edge region. The thin solid black vertical lines indicate the onset day of the SSW ( 6 January, $\sim 2$ days before the vortex split) and the day when the offspring vortices reunited (30 January).

may have hindered reformation of $\mathrm{ClONO}_{2}$ (typically the initial deactivation pathway in the Arctic; e.g., Douglass et al., 1995; Santee et al., 2008) and thus delayed deactivation. ClO dropped to near 0 by about 5 February, over 1 month after PSCs were last observed.
The vortex-averaged ozone time series (Fig. 9e) shows decreasing values at levels between about 450 and $600 \mathrm{~K}$ from before mid-December until the vortex split. After the vortex split, increases were seen at the higher levels, but ozone decreased more rapidly between about 450 and $550 \mathrm{~K}$. After the 


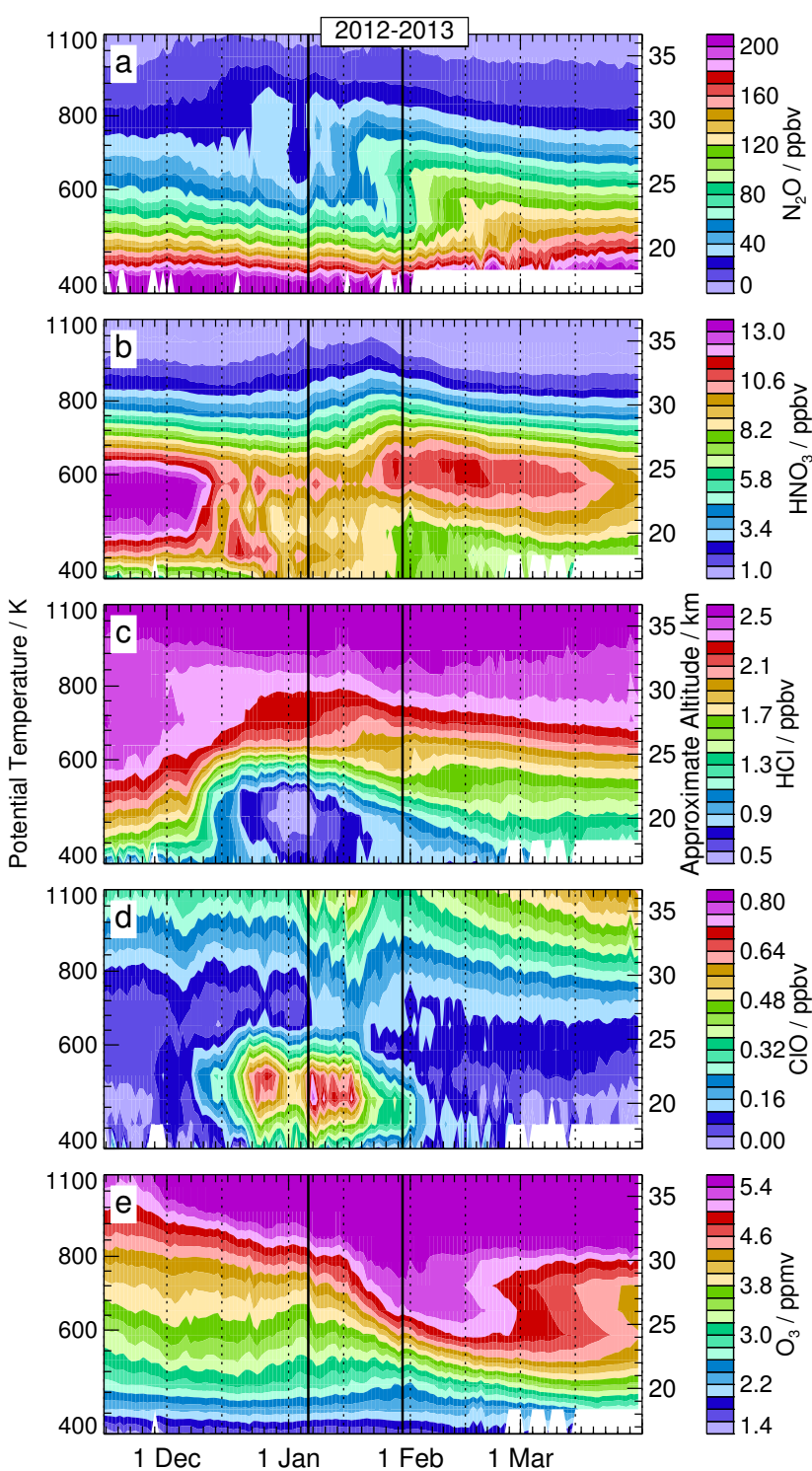

Figure 9. Potential temperature/time series of vortex-averaged (within the $1.4 \times 10^{-4} \mathrm{~s}^{-1} \mathrm{sPV}$ contour) (a) $\mathrm{N}_{2} \mathrm{O}$ (color bar range 0 to 210 ppbv), (b) $\mathrm{HNO}_{3}$ (color bar range 1.0 to $13.6 \mathrm{ppbv}$ ), (c) $\mathrm{HCl}$ (color bar range 0.5 to $2.6 \mathrm{ppbv}$ ), (d) $\mathrm{ClO}$ (color bar range 0 to $0.84 \mathrm{ppbv}$ ), and (e) $\mathrm{O}_{3}$ (color bar range 1.4 to $5.6 \mathrm{ppmv}$ ) derived from MLS data. The thin solid black vertical lines indicate the onset day of the SSW (6 January, $\sim 2$ days before the vortex split) and the day when the offspring vortices reunited (30 January).

vortices merged, vortex-averaged ozone increased throughout the lower stratosphere, consistent with some mixing during their reunification.

\subsection{Trace gas evolution in the offspring vortices}

The maps shown in Fig. 7 indicated differences in the dynamical and chemical characteristics of the two offspring vortices in January 2013. Figure 11 shows the detailed evolu-
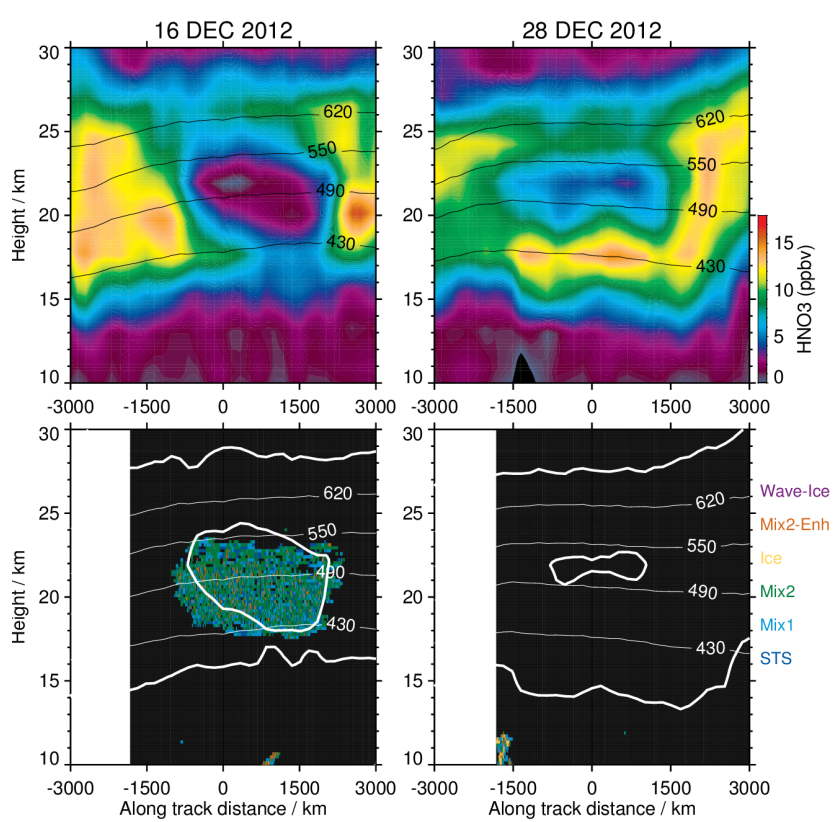

Figure 10. $\mathrm{MLS}_{\mathrm{HNO}}$ (color bar range 0 to $18 \mathrm{ppbv}$ ) along an orbit track (top panels) and co-located CALIPSO PSC classification (bottom panels, see text) on 16 and 28 December 2012. The orbit tracks shown on each day are very close to the same position and orientation, extending over Iceland approximately parallel to the easternmost part of the Greenland coast. The zero point on the tracks is at the turnaround of the orbit, that is, the point closest to the pole. Overlaid labeled lines are potential temperature contours. Overlaid thick white contour in the bottom panels is the 5 ppbv $\mathrm{HNO}_{3}$ contour.

tion of MLS trace gases at $490 \mathrm{~K}$ in the individual offspring vortices, in the context of vortex conditions. The Canadian vortex (in dark red) encompassed about $20-40 \%$ of the total vortex area (dots on Fig. 11b). As was apparent on individual days in Fig. 7, the Canadian vortex was closer to the pole than the Siberian vortex (in orange) in early January but moved to near $50^{\circ} \mathrm{N}$ latitude by mid-January (Fig. 11a), completely equatorward of polar night. The average latitude of the Siberian vortex was near $60^{\circ} \mathrm{N}$ in early January to over $70^{\circ} \mathrm{N}$ in late January, with a corresponding late-January decrease in SVA (though $60-80 \%$ of that vortex still experienced sunlight).

Average temperatures in January were considerably lower in the Canadian than in the Siberian vortex (Fig. 11c). Even in the Canadian vortex, however, the minimum temperatures were near or higher than $T_{\mathrm{NAT}}$ (the minimum temperatures in Fig. 2 reflect those in the Canadian vortex). $\mathrm{N}_{2} \mathrm{O}$ values (Fig. 11d) dropped steadily in both vortices until about 24 January. A small, brief increase at the time of the vortex split suggests transient mixing into the Siberian vortex, and a small increase in $\mathrm{N}_{2} \mathrm{O}$ in the Canadian vortex in the last few days before the merge suggests increased mixing into that offspring vortex. On average, $\mathrm{N}_{2} \mathrm{O}$ values were similar in 

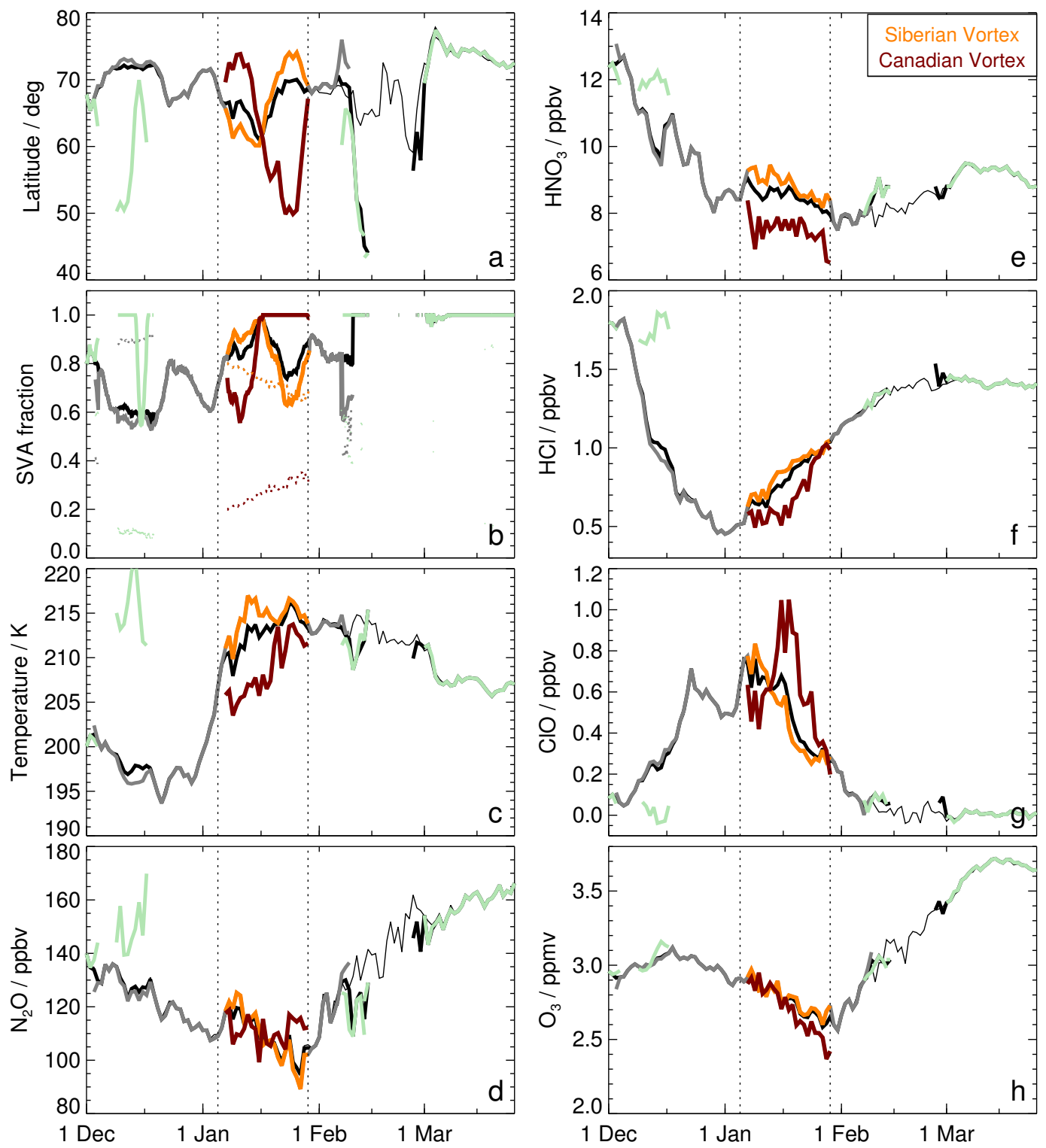

Figure 11. Characteristics of individual offspring vortices in 2012/13 at $490 \mathrm{~K}$ : (a) vortex-averaged latitude (degrees), (b) SVA expressed as a fraction of the vortex area (fine dotted lines show the fraction of total vortex area in each offspring vortex), vortex-averaged MLS (c) temperature, (d) $\mathrm{N}_{2} \mathrm{O}$, (e) $\mathrm{HNO}_{3}$, (f) $\mathrm{HCl}$, (g) $\mathrm{ClO}$, and (h) $\mathrm{O}_{3}$. Thick black lines show the fields for the sum over all vortices with area greater than $1 \%$ of a hemisphere; thin black lines in vortex-averaged plots show "bulk" average (including individual regions with area less than $1 \%$ of the hemisphere). Individual vortices are shown as thick grey and colored lines, with the "Siberian" and "Canadian" vortices in January shown in orange and dark red, respectively, and smaller offspring vortices at other times in light green. Thin vertical dotted lines are on 6 January (the onset of the major SSW, $\sim 2$ days before the vortex split) and 30 January (when the offspring vortices merged).

the two offspring vortices during the period when they were separated.

The average $\mathrm{HNO}_{3}$ values seen in Fig. 11e in the Canadian vortex were about 1 ppbv lower than those in the larger Siberian vortex and usually below any previously observed by Aura MLS in the Arctic in January (see below). Because the vortices experienced sunlight over much of their areas during January, the possibility that photolysis (usually very slow in the vortex in December and January) contributes to the persistence of low $\mathrm{HNO}_{3}$ values should be considered. The photochemical lifetime of $\mathrm{HNO}_{3}$ in winter greatly exceeds 30 days for latitudes poleward of $60^{\circ} \mathrm{N}$ (comparable to the location of the vortex in December) and ranges from $\sim 20$ to over 30 days at $50^{\circ}$ (near the position of the Canadian vortex in late January) (e.g., Austin et al., 1986). Similarly, the photodissociation rates given by Kawa et al. (1992) as a function of solar zenith angle suggest a lifetime against photolysis of 60 days or more for the vortex conditions in January 2013, 

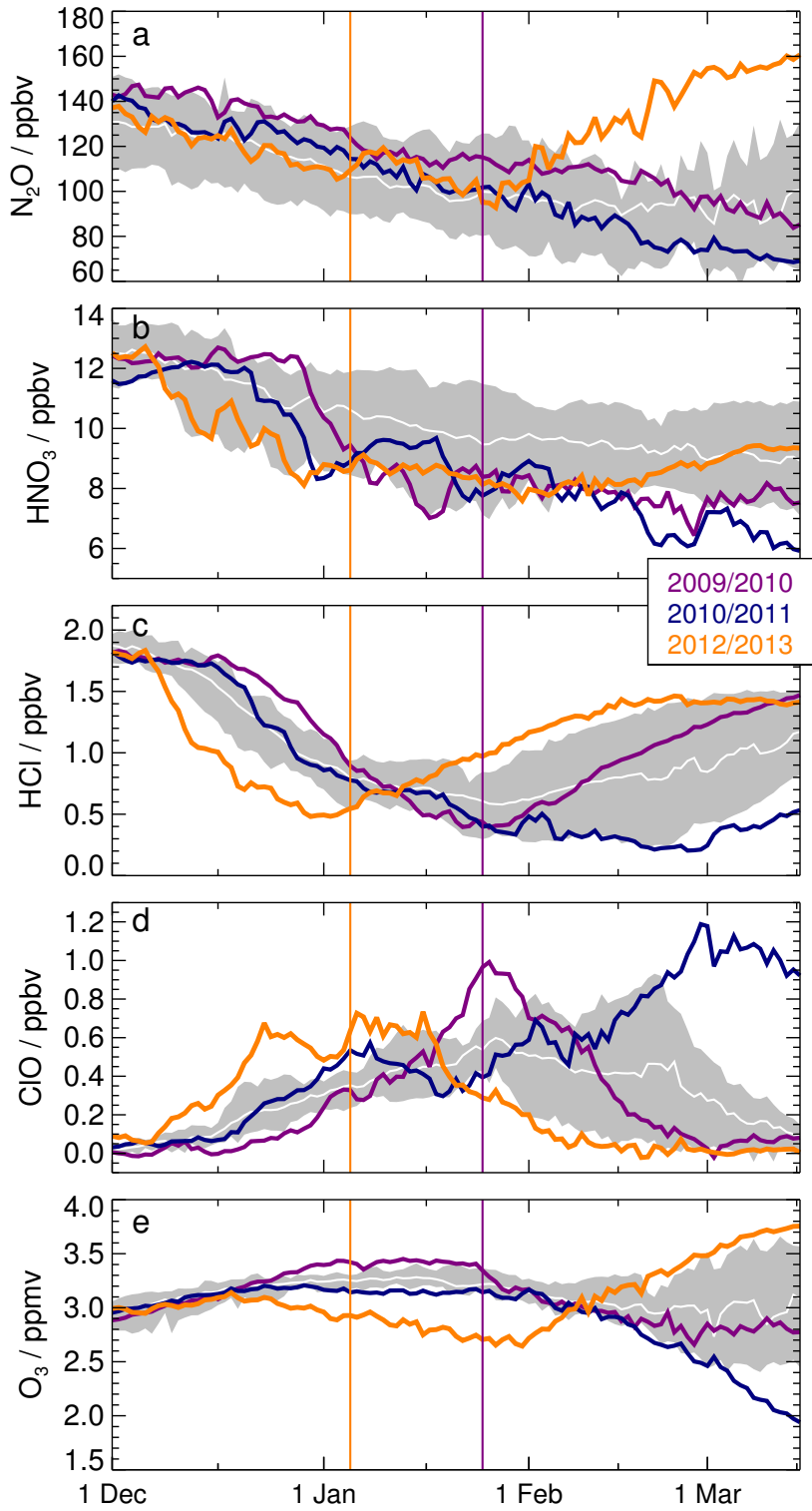

Figure 12. Vortex-averaged MLS trace gases at $490 \mathrm{~K}$, in 2012/13 (orange), 2010/11 (blue), and 2009/10 (purple) compared with the range (grey shading) and average (white line) for the other Arctic winters in 2004/05 through 2013/14. (a) $\mathrm{N}_{2} \mathrm{O}$, (b) $\mathrm{HNO}_{3}$, (c) $\mathrm{HCl}$, (d) $\mathrm{ClO}$, and (e) $\mathrm{O}_{3}$. Vertical purple and orange lines show the onset dates of the SSWs in 2010 and 2013, respectively.

except for those of the Canadian vortex in late January, when the expected lifetime is near 30 days. Photolysis of $\mathrm{HNO}_{3}$ may thus have played some role (albeit small) in maintaining low $\mathrm{HNO}_{3}$ in the Canadian vortex in January 2013. But the primary mechanism leading to lower $\mathrm{HNO}_{3}$ in the Canadian than in the Siberian vortex is likely to have been the non-uniform distribution of denitrification within the parent vortex arising from the persistent location of the cold region towards that side of the vortex before the split (see Fig. 1 and the Supplement).
The large PSC particle surface area present within the vortex through most of December 2012 (Fig. 4) resulted in strong chlorine activation beginning in early December, seen both in the large drop in $\mathrm{HCl}$ and the increase in $\mathrm{ClO}$. As noted above, maxima in $\mathrm{ClO}$ correspond closely to periods when most of the vortex area was in sunlight. In particular, the peaks in late December and in the larger Siberian vortex in early January were contemporaneous with increases in SVA for those vortices, and the dramatic increase in $\mathrm{ClO}$ in the Canadian vortex after mid-January (about 2 weeks after the last occurrence of PSCs) corresponds to the time when that vortex moved fully into latitudes that received sunlight. $\mathrm{ClO}$ was significantly higher in the Canadian offspring vortex; that $\mathrm{HCl}$ was also significantly lower suggests that the difference in activation between the vortices is not entirely accounted for by differing sunlight levels. This is likely partly due to nonuniform activation in the two offspring vortices at the time of the split - the morphology at that time was similar to that seen on 11 January 2013 in Fig. 7, with the Canadian vortex more completely filled with very low $\mathrm{HCl}$ values than the Siberian vortex. $\mathrm{HCl}$ began to increase later in the Canadian than in the Siberian vortex but increased more rapidly once it began. Since the Canadian vortex remained outside the area of polar night after mid-January, the decrease in $\mathrm{ClO}$ in that vortex arose entirely from deactivation; that is, none of the observed decline in $\mathrm{ClO}$ came about through changes in chlorine partitioning induced by changes in sunlight exposure. This unequivocal observation of deactivation well before the vernal equinox is unique in the MLS record. Since photolysis of $\mathrm{HNO}_{3}$ is the primary source of the $\mathrm{NO}_{2}$ needed for $\mathrm{ClONO}_{2}$ production (e.g., Kawa et al., 1992; Douglass et al., 1995; Santee et al., 2008), the depressed $\mathrm{HNO}_{3}$ abundances in the Canadian vortex may have inhibited that deactivation pathway. That $\mathrm{HCl}$ in the Canadian vortex began to increase concurrently with the rapid decrease in $\mathrm{ClO}$ is consistent with deactivation occurring through $\mathrm{HCl}$ formation to a greater degree than is typical in the Arctic, as discussed in more detail below.

Ozone began to decrease steadily by mid-December (Fig. 11h), indicating that it was decreasing faster via chemical loss than it was being replenished by diabatic descent. The early onset of rapid chemical ozone loss is consistent with $60-80 \%$ of the vortex being exposed to sunlight in December and the consequent high $\mathrm{ClO}$ values. On average, ozone was distributed fairly uniformly between the two offspring vortices at the time of the split. Ozone decreased slightly faster in the Canadian vortex in middle to late January, consistent with greater exposure to sunlight and the higher $\mathrm{ClO}$ values in that vortex. The observed ozone decreases from the maximum in mid-December were about 0.6 and 0.8 ppmv in the Siberian and Canadian vortices, respectively. 


\subsection{Comparison with other Arctic winters}

To compare the polar processing in 2012/13 with that in the other Arctic winters observed by Aura MLS, we show the evolution of $\mathrm{N}_{2} \mathrm{O}, \mathrm{HNO}_{3}, \mathrm{HCl}, \mathrm{ClO}$, and $\mathrm{O}_{3}$ averaged over the total vortex area (that is, encompassing all offspring vortices) (Fig. 12). The evolution of $\mathrm{N}_{2} \mathrm{O}$ in December 2012 and January 2013 (Fig. 12a) was very similar to that in the other Arctic winters observed by Aura MLS, indicating similar patterns of descent in the vortex. That this was the case for approximately 1 month following the vortex split in 2013 provides additional evidence of how well the offspring vortices remained isolated. After late January, when the vortices coalesced, $\mathrm{N}_{2} \mathrm{O}$ rose to values much higher than any previously observed at that time of year.

Vortex-averaged $\mathrm{HNO}_{3}$ (Fig. 12b) in December was among the lowest in the Aura record, with the abrupt drop in early December indicating the onset of extensive PSC activity. $\mathrm{HNO}_{3}$ values remained unusually low through early February 2013. The overall vortex average values were roughly comparable to those in January and February 2010 and 2011, both winters in which substantial denitrification has been reported (e.g., Khosrawi et al., 2011; Manney et al., 2011; Wohltmann et al., 2013). In those winters, however, PSCs persisted at that time, so the degree to which the low values arose from denitrification rather than sequestration in PSCs is difficult to determine.

Consistent with the low temperatures and persistently large PSC surface area (Figs. 2-4), extensive chlorine activation was observed earlier than in any of the other Arctic winters during which Aura measurements are available, as seen in the large drop in $\mathrm{HCl}$ in early December 2012 in Fig. 12c. The unusually extensive exposure to sunlight near the time of winter solstice resulted in strongly elevated $(\sim 0.5-0.7 \mathrm{ppbv}$ in the vortex average) $\mathrm{ClO}$ much earlier than in any other winter shown here. Activation also began in early December in the 2011/12 winter (Bernhard et al., 2012; WMO, 2014), but $\mathrm{HCl}$ values were less extreme (defining the bottom of the envelope in Fig. 12c), and maximum $\mathrm{ClO}$ values in December remained below 0.4 ppbv (not shown). In both 2010 and 2013, ClO remained well above 0 for about 1 month (slightly longer in 2013) after the SSWs. In 2013, ClO remained near its maximum value for over 2 weeks after temperatures rose above $T_{\mathrm{NAT}}$, while in 2010, ClO began decreasing immediately after the SSW despite temperatures remaining below $T_{\text {NAT }}$ for about 2 more weeks (Fig. 2).

Examination of $\mathrm{ClO}$ for each individual year indicates that the time for $\mathrm{ClO}$ to decline to near-zero values in 2012/13 after reaching its peak ( $\sim 25-30$ days) was similar to that in 2010/11 and 2009/10, slightly longer than the 15-20 days in the other observed years. (When deactivation begins before the vernal equinox, however, varying sunlight exposure also affects the timing of the $\mathrm{ClO}$ decline.) The time for $\mathrm{HCl}$ to reach a maximum from the beginning of a relatively monotonic rise ( $\sim 30-35$ days) in 2012/13 was shorter than that in other years observed by Aura MLS $(\sim 40$ 60 days). Ozone abundances during the period when deactivation was occurring in 2012/13 were $\sim 2.5-2.7$ ppmv, about $0.5-0.7$ ppmv lower than those in the years when $\mathrm{ClO}$ declined most rapidly. Douglass and Kawa (1999) and Santee et al. (2008) have shown cases where low ozone amounts in the Arctic favored $\mathrm{HCl}$ formation. Thus, both low $\mathrm{HNO}_{3}$ and low $\mathrm{O}_{3}$ abundances can affect Arctic chlorine deactivation. A thorough analysis of interannual variability in chlorine partitioning in the MLS record would require detailed chemical modeling and is beyond the scope of this paper, but the relatively slow decline in $\mathrm{ClO}$ and relatively rapid rise in $\mathrm{HCl}$ in the presence of unusually low $\mathrm{HNO}_{3}$ and $\mathrm{O}_{3}$ abundances is consistent with previous observations under similar conditions.

The ozone decrease beginning in mid-December 2012 was earlier than that in any other Arctic winter observed by Aura. By late January 2013, $\mathrm{O}_{3}$ was about 0.4 ppmv lower than in any of the nine other winters shown in Fig. 12. The observed ozone decrease of about $0.6 \mathrm{ppmv}$ between mid-December and early February is about double the amount of previously observed reductions in this interval, which were less than $\sim 0.3$ ppmv. Since descent was replenishing vortex $\mathrm{O}_{3}$ during this period, the chemical loss was larger than the observed decrease. In the following section, we use the reverse trajectory and Lagrangian Trajectory Diagnostic methods described in Sect. 2.3.3 with MLS $\mathrm{N}_{2} \mathrm{O}, \mathrm{HNO}_{3}$, and $\mathrm{O}_{3}$ to estimate denitrification and chemical loss amounts.

\section{Estimates of chemical ozone loss}

Reverse trajectory (see Sect. 2.3.3) estimates of chemical $\mathrm{O}_{3}$ loss and denitrification at $490 \mathrm{~K}$ in December 2012 and January 2013 are shown in Fig. 13. The $\mathrm{N}_{2} \mathrm{O}$ values (Fig. 13a and b) indicate uncertainties in the transport calculation, and suggest that the descent in the RT calculations is too strong or mixing too weak, in that the modeled $\mathrm{N}_{2} \mathrm{O}$ drops faster than that observed. After about 20 January, when the vortices are moving back together and mixing is starting to increase, the RT underestimate of $\mathrm{N}_{2} \mathrm{O}$ becomes larger. Transport errors are larger in the Canadian vortex than in the Siberian vortex. The maximum difference between passive RT and MLS ozone in both the total vortex average and individual offspring vortex averages is about $0.85 \mathrm{ppmv}$ on 26 January (Fig. 13d), with values of about $0.7 \mathrm{ppmv}$ on 20 January, when overall transport errors as indicated by $\mathrm{N}_{2} \mathrm{O}$ are still relatively small. This agrees well with a rough estimate of chemical ozone loss using MLS $\mathrm{N}_{2} \mathrm{O}$ to estimate vortex-averaged descent as per, e.g., Manney et al. (2006) (not shown) that indicates a maximum of just over $0.7 \mathrm{ppmv}$ vortex-averaged ozone loss on about 20 January near $500 \mathrm{~K}$. Similar calculations for other years (not shown) give chemical loss estimates between 1 December and 20 January ranging from about 0.2 to $0.4 \mathrm{ppmv}$ at $490 \mathrm{~K}$. As was the case 

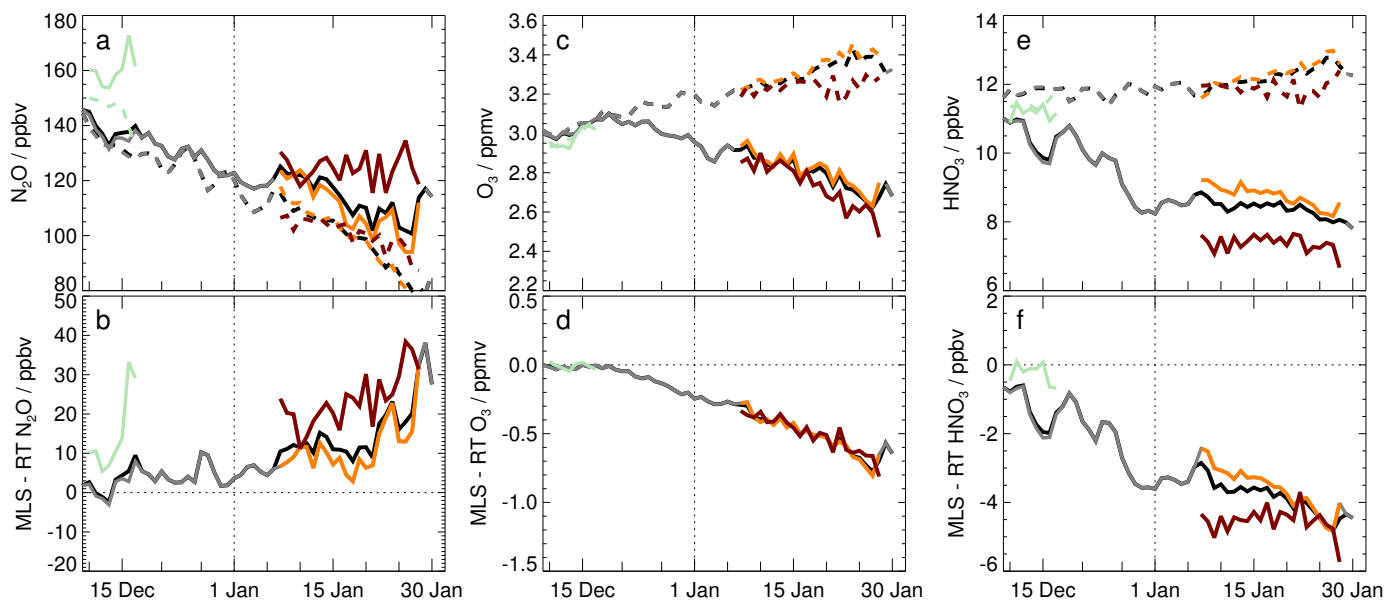

Figure 13. Vortex-averaged (left to right) $\mathrm{N}_{2} \mathrm{O}, \mathrm{O}_{3}$, and $\mathrm{HNO}_{3}$ from $\mathrm{MLS}$ (solid lines) and RT passive subtraction (dashed lines) calculations (see text) at $490 \mathrm{~K}$ from 8 December 2012 through January 2013. (a), (c), and (e) show mixing ratios in each of the vortices present; (b), (d), and (f) show the difference between MLS and RT (passively transported) values, indicative of transport uncertainties for $\mathrm{N}_{2} \mathrm{O}$, and chemical and/or microphysical changes for $\mathrm{O}_{3}$ and $\mathrm{HNO}_{3}$. Line colors are as in Fig. 11.

in 2012/13, the calculations also indicate larger-than-typical transport $\left(\mathrm{N}_{2} \mathrm{O}\right)$ errors in 2005/06, 2008/09, and 2011/12, all years with strong January SSWs; this indicates greater difficulty in simulating transport under disturbed conditions. The lack of significant improvement with more frequent reinitialization (noted in Sect. 2.3.3) suggests that these increasing errors are more closely related to larger inaccuracies in the 3-D motion fields under disturbed conditions (and possibly limitations in the MLS data's ability to capture the finer-scale structure that develops under such conditions) than to trajectory errors accumulated over the duration of the longer runs. Similar patterns of and interannual variability in estimated ozone loss are found at 460 and $520 \mathrm{~K}$; for $2012 / 13$, the RT calculations indicate $\sim 0.6 \mathrm{ppmv}(\sim 0.7 \mathrm{ppmv})$ ozone loss at $460 \mathrm{~K}(520 \mathrm{~K})$. Transport errors become larger at $550 \mathrm{~K}$, but many years show significant ozone loss (ranging from 0.3 to 0.7 ppmv) by 20-30 January. About 0.7 ppmv ozone loss was estimated at $550 \mathrm{~K}$ in 2012/13.

The RT method was also used to estimate the chemical and microphysical processes affecting $\mathrm{HNO}_{3}$ (Fig. 13e and f). In the absence of PSC formation, denitrification, and photolysis, the RT model predicts a slight increase in vortex $\mathrm{HNO}_{3}$ from 8 December through January. Instead, observed $\mathrm{HNO}_{3}$ drops substantially. This is consistent with sequestration in PSCs during the period before about 20 December, when observations show large oscillations over a few days that are correlated with temperature changes. After a further rapid drop starting about 21 December, $\mathrm{HNO}_{3}$ values remained low through January. Examination of maps of the RT/observed $\mathrm{HNO}_{3}$ differences (not shown) indicates that the depression in observed with respect to passively transported $\mathrm{HNO}_{3}$ was uniformly distributed throughout the vortex during January. These results are consistent with vortex-averaged denitrification of about 4 ppbv. Exami- nation of a run initialized on 1 January (not shown) indicates good agreement between RT and MLS $\mathrm{HNO}_{3}$ throughout the month, with little change in either, confirming that photolysis did not significantly affect vortex $\mathrm{HNO}_{3}$.

Livesey et al. (2015) estimated chemical ozone loss during January through March for the 2004/05 through 2012/13 Arctic winters using the MLS Match technique (see also Sect. 2.3.3). We use similar calculations for the December/January period to compare early-winter chemical ozone loss in 2012/13 with that in previous years observed by Aura MLS (Fig. 14). The values for 2012/13 using this Match method are somewhat smaller than those from the RT and vortex-averaged descent estimates described above, and Livesey et al. (2015) show that their winter-long estimates tend to be in the lower part of the range of values obtained using several other methods and data sets. Uncertainties in Arctic ozone loss estimates are consistently large (e.g., Brakebusch et al., 2013; Livesey et al., 2015), but interannual differences in estimates derived from each data set/method tend to agree well (e.g., Manney et al., 2011), indicating that comparisons of relative values calculated using the same method across the years are robust. The calculations for 1 December through 20 January (Fig. 14, left panel) indicate about twice as much chemical loss near $500 \mathrm{~K}$ in $2012 / 13$ as the largest in the previous years. In addition, significant chemical loss before 20 January extended down to $450 \mathrm{~K}$ in 2012/13 but not in any of the previous winters observed by Aura MLS. The previous years with largest ozone loss at $500 \mathrm{~K}$ prior to 20 January were 2005/06 and 2008/09, both years with strong prolonged SSWs in late January. This is consistent with the disturbed vortex prior to these SSWs experiencing more sunlight than is typical.

By 31 January (Fig. 14, right panel), the MLS Match calculations show chemical loss commencing in most of the 


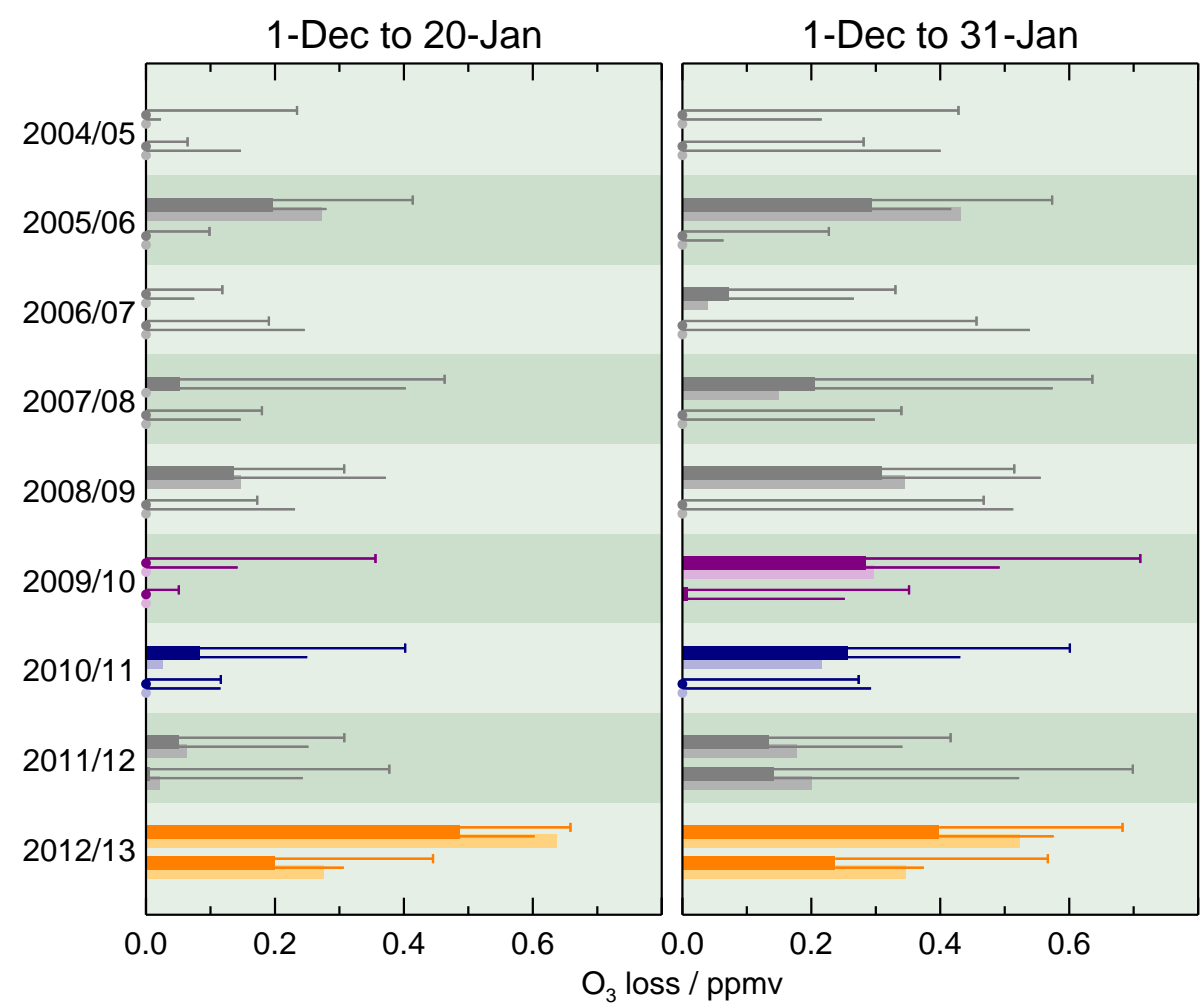

Figure 14. Chemical ozone loss estimates for 1 December through (left) 20 January and (right) 31 January from MLS Match (Livesey et al., 2015) for the 2004/05 through 2012/13 Arctic winters. Integrated ozone loss for each Arctic early winter, in $25 \mathrm{~K}$ potential temperature bins centered at $500 \mathrm{~K}$ (top bar of pair for each year) and $450 \mathrm{~K}$ (bottom bar of each pair), is shown as wide bars, with overlapping wide pale bars showing the calculations using "stricter" match requirements (see Sect. 2.3.3). Dots on the left-hand axis indicate where the estimated ozone change was 0 or positive, indicating no chemical loss. Thin lines extending to the right of the wide bars show uncertainties in ozone calculated assuming $\mathrm{N}_{2} \mathrm{O}$ changes are ascribed to errors in descent (upper lines, with "tails" at right hand end) or mixing across the vortex edge (lower lines, with no tails). As in previous figures, 2009/10, 2010/11, and 2012/13 are highlighted in purple, blue, and orange, respectively.

years studied. In 2012/13, the estimates decrease slightly and the uncertainties increase between 20 and 30 January, consistent with the results of the RT calculations that showed increasing errors in transport during that period. The large values in 2009/10 are consistent with the disturbed but very cold vortex in mid-January 2010. In most years, significant early-winter ozone loss does not extend down to $450 \mathrm{~K}$ even by 31 January. Only 2011/12 shows significant ozone loss at $450 \mathrm{~K}$ between 20 and 31 January (but not before 20 January). As noted above, there was also a prolonged SSW in 2011/12 (though that event had a less dramatic and abrupt effect on the lower stratospheric circulation), and some similarities are seen in trace gas evolution.

The results from these chemical ozone loss estimates show that disturbances to the lower stratospheric vortex prior to strong SSWs can be an important factor in controlling earlywinter ozone loss, largely because they result in significantly greater exposure of the vortex to sunlight during the interval before chlorine is deactivated. In 2012/13, the period with a highly disturbed vortex containing significant amounts of active chlorine persisted for approximately 1 month after the
SSW and consequent increase of temperatures above $T_{\mathrm{NAT}}$, facilitating exceptional early-winter chemical ozone loss.

\section{Conclusions}

We have described the evolution of meteorological conditions, polar stratospheric clouds, and trace gases in the 2012/13 Arctic winter. Our results give a detailed view of the processes, associated with an SSW that split the vortex in early January 2013, that led to more chemical ozone loss in December 2012 and January 2013 than previously observed during that period in the Arctic. Figure 15 provides a schematic of the processes leading to this unusual earlywinter ozone loss.

Temperature and vortex information from the MERRA and GEOS-5.9.1 data assimilation system fields, and PSC information from CALIPSO, show the following conditions.

- The lower stratosphere was unusually cold in December 2012, with a period of $\sim 3$ weeks with temperatures below the frost point. 


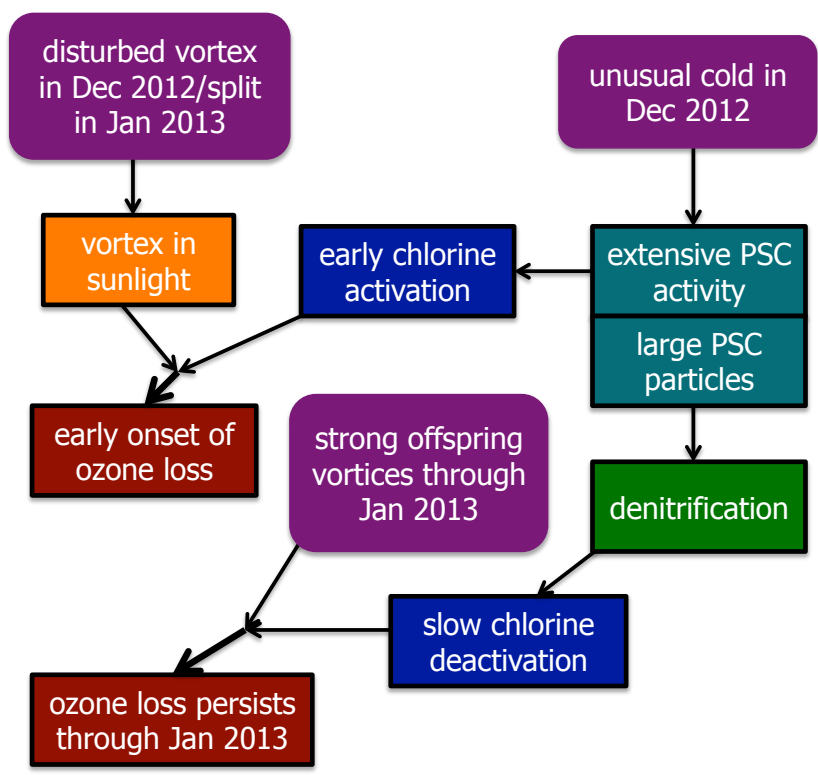

Figure 15. Block diagram of the processes leading to unusual earlywinter chemical ozone loss in 2012/13. Purple boxes show the key dynamical processes that, in combination, resulted in the unusual early-winter chemical processing. Blue-green and blue boxes show PSC and chlorine processes, respectively. Orange box indicates sunlight exposure and green box denitrification. Both phenomena going into each dark red box were necessary for the chemical ozone loss to take place.

- While temperatures on a given date at a given level did not in general set records, they were more consistently low over a deeper layer than usual in December 2012, resulting in greater potential for chlorine activation and ozone loss than in other winters with comparably early SSWs.

- During the cold period in December 2012, the total PSC particle surface area within the vortex was larger than that in any of the other seven winters observed by CALIPSO.

- The PSCs present during the cold period in December 2012 included a substantial fraction of NAT mixtures with large particles that can sediment quickly.

- Temperatures rose abruptly above the chlorine activation threshold throughout the lower stratosphere a few days before the 6 January onset of the major SSW and the $\sim 8$ January vortex split.

- The two offspring vortices remained separate, strong (i.e., effective transport barriers), and largely in regions receiving sunlight until they merged at the end of January.

- After the vortex split, temperatures in the smaller (20$40 \%$ of total vortex area) "Canadian" vortex were sig- nificantly lower than those in the larger "Siberian" vortex, though both remained entirely above $T_{\mathrm{NAT}}$.

- After the offspring vortices merged at the end of January, the reunited vortex weakened and enhanced mixing occurred; by mid-February, the vortex no longer represented a significant transport barrier.

- The Canadian vortex was entirely outside of polar night after mid-January, with an average latitude of $50-60^{\circ} \mathrm{N}$

The peculiar meteorological conditions and PSC evolution detailed above gave rise to the following responses in the MLS trace gases:

- $\mathrm{N}_{2} \mathrm{O}$ observations indicate that confined descent in the offspring vortices continued until they merged in late January.

- After a period of about 3 weeks in December with a large area of PSC mixtures containing solid NAT particles, vortex $\mathrm{HNO}_{3}$ remained very low through early February, indicating denitrification.

- $\mathrm{HNO}_{3}$ was significantly lower (by about $1 \mathrm{ppbv}$ ) in the Canadian than in the Siberian vortex, largely as a result of more persistent PSC activity in that portion of the parent vortex before the split.

- $\mathrm{HCl}$ and $\mathrm{ClO}$ indicate earlier chlorine activation than previously observed by Aura MLS in the Arctic.

- Peaks in $\mathrm{ClO}$ were concurrent with periods when most of the vortex was exposed to sunlight. From midthrough late January, $\mathrm{ClO}$ was significantly higher (by $\sim 0.4$ ppbv) in the Canadian than in the Siberian vortex as a result of greater sunlight exposure.

- Chlorine deactivation in January began later in the Canadian than in the Siberian vortex, likely resulting from lower $\mathrm{HNO}_{3}$ abundances reducing deactivation into $\mathrm{ClONO}_{2}$.

- The observed ozone values and decrease from midDecember to early February were unprecedented, with about 0.4 ppmv less ozone in late January 2013 than in any other winter in the 2004/05-2014/15 MLS record.

It was thus a unique combination of dynamical processes that is, persistently low temperatures and a disturbed vortex in December 2012 and the split into two vortices that individually remained isolated through January - that led to the unusual chemical processing and ozone loss (illustrated in Fig. 15).

Estimates of chemical ozone loss using passive subtraction and vortex-averaged descent methods indicate $\sim 0.7$ $0.8 \mathrm{ppmv}$ maximum vortex-averaged chemical loss near 
500 K. Passive subtraction calculations also indicate vortexwide denitrification, resulting in a deficit of about $4 \mathrm{ppbv}$ in vortex-averaged $\mathrm{HNO}_{3}$ through January.

While quantitative uncertainties in early-winter ozone loss estimates are large, calculations using a single method and data set have been shown to give a robust picture of interannual variability. Comparisons of calculations using a Match method for each winter observed by Aura MLS show that chemical loss in December 2012 and January 2013 was larger than that in any of the other years in that record. While some of those years had significant loss during that period near $500 \mathrm{~K}$, only in $2012 / 13$ was that early-winter ozone loss large down through $450 \mathrm{~K}$.

Significant ozone loss before late January was previously seen only in 2005/06 and 2008/09, winters with strong SSWs in January. This emphasizes the importance of disturbances of the lower stratospheric vortex prior to SSWs in the development of conditions promoting chemical ozone destruction in early winter. In particular, disturbed vortices prior to SSWs tend to experience more sunlight than those in overall colder, more quiescent winters, allowing substantial ozone destruction in those cases where temperatures are also persistently low enough for extensive chlorine activation.

The combination of dynamical conditions that led to exceptional chemical ozone loss in December 2012 and January 2013 is, so far, unique in the record of Arctic winter variability. The extensive suite of measurements pertinent to lower stratospheric polar processing available from MLS and CALIPSO for the past decade allowed detailed diagnosis of the processes leading to the unusual early-winter ozone loss in 2012/13. Just 2 years earlier, Arctic winter conditions combined to produce unprecedented springtime ozone loss, arguably resulting in the first "Arctic ozone hole". The occurrence in two recent winters of vastly different permutations in lower stratospheric meteorology, each unlike any previously observed, and the impact of those dynamical conditions on polar winter chemical processes argue for the importance of continuing comprehensive composition measurements to enable diagnosis of future extreme variations in polar processing and Arctic ozone loss.

\section{The Supplement related to this article is available online at doi:10.5194/acp-15-5381-2015-supplement.}

Acknowledgements. Thanks to the MLS team at JPL (especially Brian Knosp, Ryan Fuller, and William Daffer) for data processing, management, and analysis support and to Ken Minschwaner, Joan Alexander, and Sharon Sessions and her "Research and Communications" class at NMT for helpful comments/discussions; thanks to the two anonymous referees for their helpful comments. Thanks to Steven Pawson and the GMAO for their work in production/distribution of MERRA and GEOS-5.9.1 data. Work at the Jet Propulsion Laboratory, California Institute of Technology, was done under contract with the National Aeronautics and Space Administration.

Edited by: W. Lahoz

\section{References}

Achtert, P. and Tesche, M.: Assessing lidar-based classification schemes for polar stratospheric clouds based on 16 years of measurements at Esrange, Sweden, J. Geophys. Res., 119, 13861405, 2014.

Allen, D. R. and Nakamura, N.: A seasonal climatology of effective diffusivity in the stratosphere, J. Geophys. Res., 106, 7917-7935, 2001.

Arnone, E., Castelli, E., Papandrea, E., Carlotti, M., and Dinelli, B. M.: Extreme ozone depletion in the 2010-2011 Arctic winter stratosphere as observed by MIPAS/ENVISAT using a 2D tomographic approach, Atmos. Chem. Phys., 12, 9149-9165, doi:10.5194/acp-12-9149-2012, 2012.

Austin, J., Garcia, R. R., Russell III, J. M., Solomon, S., and Tuck, A. F: On the atmospheric photochemistry of nitric acid, J. Geophys. Res., 91, 5477-5485, 1986.

Bernhard, G., Manney, G., Fioletov, V., Grooß, J.-U., Heikkilä, A., Johnsen, B., Koskela, T., Lakkala, K., Müller, R., Lund Myhre, C., and Rex, M.: Ozone and UV Radiation, in: Arctic Report Card 2012, available at: http://www.arctic.noaa.gov/ reportcard (last access: 13 February 2015), 2012.

Bloom, S. C., Takacs, L. L., da Silva, A. M., and Ledvina, D.: Data assimilation using incremental analysis updates, Mon. Weather Rev., 124, 1256-1271, 1996.

Brakebusch, M., Randall, C. E., Kinnison, D. E., Tilmes, S., Santee, M. L., and Manney, G. L.: Evaluation of whole atmosphere community climate model simulations of ozone during Arctic winter 2004-2005, J. Geophys. Res., 118, 2673-2688, doi:10.1002/jgrd.50226, 2013.

Butchart, N. and Remsberg, E. E.: The area of the stratospheric polar vortex as a diagnostic for tracer transport on an isentropic surface, J. Atmos. Sci., 43, 1319-1339, 1986.

Charlton, A. J. and Polvani, L. M.: A new look at stratospheric sudden warmings. Part I: Climatology and modeling benchmarks, J. Climate, 20, 449-469, 2007.

Charlton-Perez, A. J., Polvani, L. M., Austin, J., and Li, F.: The frequency and dynamics of stratospheric sudden warmings in the 21st century, J. Geophys. Res., 113, D16116, doi:10.1029/2007JD009571, 2008.

Cohen, J., Foster, J., Barlow, M., Saito, K., and Jones, J.: Winter 2009-2010: a case study of an extreme Arctic oscillation event, Geophys. Res. Lett., 37, L17707, doi:10.1029/2010GL044256, 2010.

Coy, L. and Pawson, S.: The major stratospheric sudden warming of January 2013: analyses and forecasts in the GEOS-5 data assimilation system, Mon. Weather Rev., 143, 491-510, 2015.

Dörnbrack, A., Pitts, M. C., Poole, L. R., Orsolini, Y. J., Nishii, K., and Nakamura, H.: The 2009-2010 Arctic stratospheric winter general evolution, mountain waves and predictability of an operational weather forecast model, Atmos. Chem. Phys., 12, 36593675, doi:10.5194/acp-12-3659-2012, 2012. 
Douglass, A. and Kawa, S.: Contrast between 1992 and 1997 highlatitude spring halogen occultation experiment observations of lower stratospheric HCl, J. Geophys. Res., 104, 18739-18754, 1999.

Douglass, A. R., Schoeberl, M. R., Stolarski, R. S., Waters, J. W., III, J. M. R., Roche, A. E., and Massie, S. T.: Interhemispheric differences in springtime production of $\mathrm{HCl}$ and $\mathrm{ClONO}_{2}$ in the polar vortices, J. Geophys. Res., 100, 13967-13978, 1995.

Drdla, K. and Müller, R.: Temperature thresholds for chlorine activation and ozone loss in the polar stratosphere, Ann. Geophys., 30, 1055-1073, doi:10.5194/angeo-30-1055-2012, 2012.

Dunkerton, T. J. and Delisi, D. P.: Evolution of potential vorticity in the winter stratosphere of January-February 1979, J. Geophys. Res., 91, 1199-1208, 1986.

Fueglistaler, S., Buss, S., Luo, B. P., Wernli, H., Flentje, H., Hostetler, C. A., Poole, L. R., Carslaw, K. S., and Peter, Th.: Detailed modeling of mountain wave PSCs, Atmos. Chem. Phys., 3, 697-712, doi:10.5194/acp-3-697-2003, 2003.

Gobbi, G. P.: Lidar estimation of stratospheric aerosol properties: Surface, volume, and extinction to backscatter ratio, J. Geophys. Res., 100, 11219-11235, 1995.

Goncharenko, L., Chau, J. L., Condor, P., Coster, A., and Benkevitch, L.: Ionospheric effects of sudden stratospheric warming during moderate-to-high solar activity: case study of January 2013, Geophys. Res. Lett., 40, 4982-4986, doi:10.1002/grl.50980, 2013.

Hanson, D. and Mauersberger, K.: Laboratory studies of the nitric acid trihydrate: implications for the south polar stratosphere, Geophys. Res. Lett., 15, 855-858, 1988.

Haynes, P. and Shuckburgh, E.: Effective diffusivity as a diagnostic of atmospheric transport 1. Stratosphere, J. Geophys. Res., 105, 22777-22794, 2000.

Hitchcock, P. and Shepherd, T. G.: Zonal-mean dynamics of extended recoveries from stratospheric sudden warmings, J. Atmos. Sci., 70, 688-707, 2013.

Hitchcock, P., Shepherd, T. G., and Manney, G. L.: Statistical characterization of Arctic polar-night jet oscillation events, J. Climate, 26, 2096-2116, 2013.

Hommel, R., Eichmann, K.-U., Aschmann, J., Bramstedt, K., Weber, M., von Savigny, C., Richter, A., Rozanov, A., Wittrock, F., Khosrawi, F., Bauer, R., and Burrows, J. P.: Chemical ozone loss and ozone mini-hole event during the Arctic winter 2010/2011 as observed by SCIAMACHY and GOME-2, Atmos. Chem. Phys., 14, 3247-3276, doi:10.5194/acp-14-3247-2014, 2014.

Hostetler, C. A., Liu, Z., Reagan, J., Vaughan, M., Winker, D., Osborn, M., Hunt, W. H., Powell, K. A., and Trepte, C.: CALIOP Algorithm Theoretical Basis Document: Calibration and Level 1 Products, Tech. Rep., NASA Langley Research Center, location is Hampton, VA USA, PC-SCI-201, NASA Langley Research Center, available at: http://www-calipso.larc.nasa.gov/resources/ pdfs/PC-SCI-201v1.0.pdf (last access: 13 February 2015), 2006.

Hunt, W. H., Winker, D. M., Vaughan, M. A., Powell, K. A., Lucker, P. L., and Weimer, C.: CALIPSO lidar description and performance assessment, J. Atmos. Ocean. Tech., 26, 1214 $1228,2009$.

Kawa, S. R., Fahey, D. W., Heidt, L. E., Pollock, W. H., Solomon, S., Anderson, D. E., Loewenstein, M., Proffitt, M. H., Margitan, J. J., and Chan, K. R.: Photochemical partitioning of the reactive nitrogen and chlorine reservoirs in the high-latitude stratosphere, J. Geophys. Res., 97, 7905-7923, 1992.

Khosrawi, F., Urban, J., Pitts, M. C., Voelger, P., Achtert, P., Kaphlanov, M., Santee, M. L., Manney, G. L., Murtagh, D., and Fricke, K.-H.: Denitrification and polar stratospheric cloud formation during the Arctic winter 2009/2010, Atmos. Chem. Phys., 11, 8471-8487, doi:10.5194/acp-11-8471-2011, 2011.

Kuttippurath, J. and Nikulin, G.: A comparative study of the major sudden stratospheric warmings in the Arctic winters 2003/2004-2009/2010, Atmos. Chem. Phys., 12, 8115-8129, doi:10.5194/acp-12-8115-2012, 2012.

Kuttippurath, J., Godin-Beekmann, S., Lefèvre, F., and Goutail, F.: Spatial, temporal, and vertical variability of polar stratospheric ozone loss in the Arctic winters 2004/2005-2009/2010, Atmos. Chem. Phys., 10, 9915-9930, doi:10.5194/acp-10-9915-2010, 2010.

Kuttippurath, J., Godin-Beekmann, S., Lefèvre, F., Nikulin, G., Santee, M. L., and Froidevaux, L.: Record-breaking ozone loss in the Arctic winter 2010/2011: comparison with 1996/1997, Atmos. Chem. Phys., 12, 7073-7085, doi:10.5194/acp-12-70732012, 2012.

Lambert, A., Santee, M. L., Wu, D. L., and Chae, J. H.: A-train CALIOP and MLS observations of early winter Antarctic polar stratospheric clouds and nitric acid in 2008, Atmos. Chem. Phys., 12, 2899-2931, doi:10.5194/acp-12-2899-2012, 2012.

Lawrence, Z. D. and Manney, G. L.: Characterizing stratospheric polar vortices with algorithms for image processing and feature tracking, in preparation, 2015.

Lawrence, Z. D., Manney, G. L., Minschwaner, K., Santee, M. L., and Lambert, A.: Comparisons of polar processing diagnostics from 34 years of the ERA-Interim and MERRA reanalyses, Atmos. Chem. Phys., 15, 3873-3892, doi:10.5194/acp-15-38732015, 2015.

Limbach, S., Schömer, E., and Wernli, H.: Detection, tracking and event localization of jet stream features in 4-D atmospheric data, Geosci. Model Dev., 5, 457-470, doi:10.5194/gmd-5-457-2012, 2012.

Livesey, N. J.: Aura Microwave Limb Sounder Lagrangian Trajectory Diagnostics Users' guide and file description document, Tech. rep., Jet Propulsion Laboratory, location is Pasadena, CA USA, available at: http://mls.jpl.nasa.gov/data/ltd.php (last access: 13 February 2015), 2013.

Livesey, N. J., Read, W. G., Froidevaux, L., Lambert, A., Manney, G. L., Pumphrey, H. C., Santee, M. L., Schwartz, M. J., Wang, S., Cofield, R. E., Cuddy, D. T., Fuller, R. A., Jarnot, R. F., Jiang, J. H., Knosp, B. W., Stek, P. C., Wagner, P. A., and Wu, D. L.: EOS MLS Version 3.3/3.4 Level 2 data quality and description document, Tech. rep., Jet Propulsion Laboratory, location is Pasadena, CA USA, available at: http://mls.jpl.nasa.gov/ (last access: 13 February 2015), 2013.

Livesey, N. J., Santee, M. L., and Manney, G. L.: A Match-based approach to the estimation of polar stratospheric ozone loss using Aura Microwave Limb Sounder observations, Atmos. Chem. Phys. Discuss., 15, 10041-10083, doi:10.5194/acpd-15-100412015, 2015.

Manney, G. L., Zurek, R. W., Gelman, M. E., Miller, A. J., and Nagatani, R.: The anomalous Arctic lower stratospheric polar vortex of 1992-1993, Geophys. Res. Lett., 21, 2405-2408, 1994a. 
Manney, G. L., Zurek, R. W., O’Neill, A., and Swinbank, R.: On the motion of air through the stratospheric polar vortex, J. Atmos. Sci., 51, 2973-2994, 1994b.

Manney, G. L., Zurek, R. W., Froidevaux, L., Waters, J. W., O'Neill, A., and Swinbank, R.: Lagrangian transport calculations using UARS data. Part II: Ozone, J. Atmos. Sci., 52, 3069-3081, 1995a.

Manney, G. L., Zurek, R. W., Lahoz, W. A., Harwood, R. S., Gille, J. C., Kumer, J. B., Mergenthaler, J. L., Roche, A. E., O’Neill, A., Swinbank, R., and Waters, J. W.: Lagrangian Transport Calculations Using UARS Data. Part I. Passive Tracers., J. Atmos. Sci., 52, 3049-3068, 1995b.

Manney, G. L., Lahoz, W. A., Swinbank, R., O’Neill, A., Connew, P. M., and Zurek, R. W.: Simulation of the December 1998 stratospheric major warming, Geophys. Res. Lett., 26, 27332736, 1999a.

Manney, G. L., Michelsen, H. A., Santee, M. L., Gunson, M. R., Irion, F. W., Roche, A. E., and Livesey, N. J.: Polar vortex dynamics during spring and fall diagnosed using trace gas observations from the Atmospheric Trace Molecule Spectroscopy instrument, J. Geophys. Res., 104, 18841-18866, 1999b.

Manney, G. L., Froidevaux, L., Santee, M. L., Livesey, N. J., Sabutis, J. L., and Waters, J. W.: Variability of ozone loss during Arctic winter (1991 to 2000) estimated from UARS Microwave Limb Sounder measurements, J. Geophys. Res., 108, 4149, doi:10.1029/2002JD002634, 2003.

Manney, G. L., Krüger, K., Sabutis, J. L., Sena, S. A., and Pawson, S.: The remarkable 2003-2004 winter and other recent warm winters in the Arctic stratosphere since the late 1990s, J. Geophys. Res., 110, D04107, doi:10.1029/2004JD005367, 2005.

Manney, G. L., Santee, M. L., Froidevaux, L., Hoppel, K., Livesey, N. J., and Waters, J. W.: EOS MLS observations of ozone loss in the 2004-2005 Arctic winter, Geophys. Res. Lett., 33, L04802, doi:10.1029/2005GL024494, 2006.

Manney, G. L., Daffer, W. H., Zawodny, J. M., Bernath, P. F., Hoppel, K. W., Walker, K. A., Knosp, B. W., Boone, C., Remsberg, E. E., Santee, M. L., Harvey, V. L., Pawson, S., Jackson, D. R., Deaver, L., McElroy, C. T., McLinden, C. A., Drummond, J. R., Pumphrey, H. C., Lambert, A., Schwartz, M. J., Froidevaux, L., McLeod, S., Takacs, L. L., Suarez, M. J., Trepte, C. R., Cuddy, D. C., Livesey, N. J., Harwood, R. S., and Waters, J. W.: Solar occultation satellite data and derived meteorological products: sampling issues and comparisons with Aura Microwave Limb Sounder, J. Geophys. Res., 112, D24S50, doi:10.1029/2007JD008709, 2007.

Manney, G. L., Santee, M. L., Rex, M., Livesey, N. J., Pitts, M. C., Veefkind, P., Nash, E. R., Wohltmann, I., Lehmann, R., Froidevaux, L., Poole, L. R., Schoeberl, M. R., Haffner, D. P., Davies, J., Dorokhov, V., Gernandt, H., Johnson, B., Kivi, R., Kyrö, E., Larsen, N., Levelt, P. F., Makshtas, A., McElroy, C. T., Nakajima, H., Parrondo, M. C., Tarasick, D. W., von der Gathen, P., Walker, K. A., and Zinoviev, N. S.: Unprecedented Arctic ozone loss in 2011, Nature, 478, 469-475, 2011.

Matthewman, N. J., Esler, J. G., Charlton-Perez, A. J., and Polvani, L. M.: A New look at stratospheric sudden warmings. Part III: Polar vortex evolution and vertical structure, J. Climate, 22, 1566-1585, 2009.

Mitchell, D. M., Charlton-Perez, A. J., and Gray, L. J.: Characterizing the Variability and Extremes of the stratospheric polar vor- tices using 2D moment analysis, J. Atmos. Sci., 68, 1194-1213, 2011.

Molod, A., Takacs, L., Suarez, M., and Bacmeister, J.: Development of the GEOS-5 atmospheric general circulation model: evolution from MERRA to MERRA2, Geosci. Model Dev. Discuss., 7, 7575-7617, doi:10.5194/gmdd-7-7575-2014, 2014.

Morris, G. A., Schoeberl, M. R., Sparling, L. C., Newman, P. A., Lait, L. R., Elson, L., Waters, J., Suttie, R. A., Roche, A., Kumer, J., and Russell III, J. M.: Trajectory mapping and applications to data from the Upper Atmosphere Research Satellite, J. Geophys. Res., 100, 16491-16505, 1995.

Nakamura, N.: Two-dimensional mixing, edge formation, and permeability diagnosed in area coordinates, J. Atmos. Sci., 53, 1524-1537, 1996.

Naujokat, B., Krüger, K., Matthes, K., Hoffmann, J., Kunze, M., and Labitzke, K.: The early major warming in December 2001 - exceptional?, Geophys. Res. Lett., 29, 2023, doi:10.1029/2002GL015316, 2002.

Pitts, M. C., Poole, L. R., and Thomason, L. W.: CALIPSO polar stratospheric cloud observations: second-generation detection algorithm and composition discrimination, Atmos. Chem. Phys., 9, 7577-7589, doi:10.5194/acp-9-7577-2009, 2009.

Pitts, M. C., Poole, L. R., Dörnbrack, A., and Thomason, L. W.: The 2009-2010 Arctic polar stratospheric cloud season: a CALIPSO perspective, Atmos. Chem. Phys., 11, 2161-2177, doi:10.5194/acp-11-2161-2011, 2011.

Pitts, M. C., Poole, L. R., Lambert, A., and Thomason, L. W.: An assessment of CALIOP polar stratospheric cloud composition classification, Atmos. Chem. Phys., 13, 2975-2988, doi:10.5194/acp-13-2975-2013, 2013.

Randel, W. J. and Boville, B. A.: Observations of a major stratospheric warming during December 1984, J. Atmos. Sci., 44, 2179-2186, 1987.

Rex, M., von der Gathen, P., Harris, N. R. P., Lucic, D., Knudsen, B. M., Braathen, G. O., Reid, S. J., De Backer, H., Claude, H., Fabian, R., Fast, H., Gil, M., Kyrö, E., Mikkelsen, I. S., Rummukainen, M., Smit, H. G., Stähelin, J., Varotsos, C., and Zaitcev, I.: In-situ measurements of stratospheric ozone depletion rates in the Arctic winter 1991/1992: A Lagrangian approach, J. Geophys. Res., 103, 5843-5853, 1998.

Rex, M., von der Gathen, P., Braathen, G. O., Harris, N. R. P., Reimer, E., Beck, A., Alfier, R., Krüger-Carstensen, R., Chipperfield, M., De Backer, H., Balis, D., O'Connor, F., Dier, H., Dorokhov, V., Fast, H., Gamma, A., Gil, M., Kyro, E., Litynska, Z., Mikkelsen, I. S., Molyneux, M., Murphy, G., Reid, S. J., Rummukainen, M., and Zerefos, C.: Chemical Ozone Loss in the Arctic Winter 1994/1995 as Determined by the Match Technique, J. Atmos. Chem., 32, 35-39, 1999.

Rex, M., Salawitch, R. J., Harris, N. R. P., von der Gathen, P., Braathen, G. O., Schulz, A., Deckelmann, H., Chipperfield, M., Sinnhuber, B.-M., Reimer, E., Alfier, R., Bevilacqua, R., Hoppel, K., Fromm, M., Lumpe, J., Küllmann, H., Kleinböhl, A., Bremer, H., von König, M., Künzi, K., Toohey, D., Vömel, H., Richard, E., Aikin, K., Jost, H., Greenblatt, J. B., Loewenstein, M., Podolske, J. R., Webster, C. R., Flesch, G. J., Scott, D. C., Herman, R. L., Elkins, J. W., Ray, E. A., Moore, F. L., Hurst, D. F., Romashkin, P., Toon, G. C., Sen, B., Margitan, J. J., Wennberg, P., Neuber, R., Allart, M., Bojkov, B. R., Claude, H., Davies, J., Davies, W., De Backer, H., Dier, H., Dorokhov, V., 
Fast, H., Kondo, Y., Kyrö, E., Litynska, Z., Mikkelsen, I. S., Molyneux, M. J., Moran, E., Nagai, T., Nakane, H., Parrondo, C., Ravegnani, F., Skrivankova, P., Viatte, P., and Yushkov, V.: Chemical depletion of Arctic ozone in winter 1999/2000, J. Geophys. Res., 107, 8276, doi:10.1029/2001JD000533, 2002.

Rex, M., Salawitch, R. J., Santee, M. L., Waters, J. W., Hoppel, K., and Bevilacqua, R.: On the unexplained stratospheric ozone losses during cold Arctic Januaries, Geophys. Res. Lett., 30, 1008, doi:10.1029/2002GL016008, 2003.

Rienecker, M. M., Suarez, M. J., Todling, R., Bacmeister, J., Takacs, L., Liu, H.-C., Gu, W., Sienkiewicz, M., Koster, R. D., Gelaro, R., Stajner, I., and Nielsen, E.: The GEOS-5 Data Assimilation System - Documentation of versions 5.0.1, 5.1.0, and 5.2.0, Tech. Rep., TM-2008-104606, NASA, Goddard Space Flight Center, Greenbelt, MD USA, 2008.

Rienecker, M. M., Suarez, M. J., Gelaro, R., Todling, R., Bacmeister, J., Liu, E., Bosilovich, M. G., Schubert, S. D., Takacs, L., Kim, G.-K., Bloom, S., Chen, J., Collins, D., Conaty, A., Da Silva, A., Gu, W., Joiner, J., Koster, R. D., Lucchesi, R., Molod, A., Owens, T., Pawson, S., Pegion, P., Redder, C. R., Reichle, R., Robertson, F. R., Ruddick, A. G., Sienkiewicz, M., and Woollen, J.: MERRA: NASA's modern-era retrospective analysis for research and applications, J. Climate, 24, 3624-3648, 2011.

Santee, M. L., Manney, G. L., Waters, J. W., and Livesey, N. J.: Variations and climatology of $\mathrm{ClO}$ in the polar lower stratosphere from UARS microwave limb sounder measurements, J. Geophys. Res., 108, 4454, doi:10.1029/2002JD003335, 2003.

Santee, M. L., MacKenzie, I. A., Manney, G. L., Chipperfield, M. P., Bernath, P. F., Walker, K. A., Boone, C. D., Froidevaux, L., Livesey, N. J., and Waters, J. W.: A study of stratospheric chlorine partitioning based on new satellite measurements and modeling, J. Geophys. Res., 113, D12307, doi:10.1029/2007JD009057, 2008.

Santee, M. L., Sander, S. P., Livesey, N. J., and Froidevaux, L.: Constraining the chlorine monoxide $(\mathrm{ClO}) /$ chlorine peroxide $(\mathrm{ClOOCl})$ equilibrium constant from Aura microwave limb sounder measurements of nighttime $\mathrm{ClO}$, P. Natl. Acad. Sci. USA, 107, 6588-6593, 2010.

Schoeberl, M. R., Lait, L. R., Newman, P. A., and Rosenfield, J. E.: The structure of the polar vortex, J. Geophys. Res., 97, 78597882, 1992.

Singleton, C. S., Randall, C. E., Chipperfield, M. P., Davies, S., Feng, W., Bevilacqua, R. M., Hoppel, K. W., Fromm, M. D., Manney, G. L., and Harvey, V. L.: 2002-2003 Arctic ozone loss deduced from POAM III satellite observations and the SLIMCAT chemical transport model, Atmos. Chem. Phys., 5, 597609, doi:10.5194/acp-5-597-2005, 2005.
Sinnhuber, B.-M., Stiller, G., Ruhnke, R., von Clarmann, T., Kellmann, S., and Aschmann, J.: Arctic winter 2010/2011 at the brink of an ozone hole, Geophys. Res. Lett., L24814, doi:10.1029/2011GL049784, 2011.

Solomon, S.: Stratospheric ozone depletion: a review of concepts and history, Rev. Geophys., 37, 275-316, 1999.

von der Gathen, P., Rex, M., Harris, N. R., Lucic, D., Knudsen, B. M., Braathen, G. O., De, H., Fabian, R., Fast, H., Gil, M., Kyrö, E., Mikkelsen, I. S., Rummukainen, M., Stähelin, J., and Varotsos, C.: Observational evidence for chemical ozone depletion over the Arctic in winter 1991-92, Nature, 375, 131-134, 1995.

Wang, L. and Chen, W.: Downward Arctic Oscillation signal associated with moderate weak stratospheric polar vortex and the cold December 2009, Geophys. Res. Lett., 37, L09707, doi:10.1029/2010GL042659, 2010.

Waters, J.W., Froidevaux, L., Harwood, R. S., Jarnot, R. F., Pickett, H. M., Read, W. G., Siegel, P. H., Cofield, R. E., Filipiak, M. J., Flower, D. A., Holden, J. R., Lau, G. K., Livesey, N. J., Manney, G. L., Pumphrey, H. C., Santee, M. L., Wu, D. L., Cuddy, D. T., Lay, R. R., Loo, M. S., Perun., V. S., Schwartz, M. J., Stek, P. C., Thurstans, R. P., Chandra, K. M., Chavez, M. C., Chen, G., Boyles, M. A., Chudasama, B. V., Dodge, R., Fuller, R. A., Girard, M. A., Jiang, J. H., Jiang, Y., Knosp, B. W., LaBelle, R. C., Lam, J. C., Lee, K. A., Miller, D., Oswald, J. E., Patel, N. C., Pukala, D. M., Quintero, O., Scaff, D. M., Snyder, W. V., Tope, M. C.,Wagner, P. A., and Walch, M. J.: The Earth Observing System Microwave Limb Sounder (EOS MLS) on the Aura satellite, IEEE Trans. Geosci. Remote Sens., 44, 1075-1092, 2006.

Wegner, T., Grooß, J.-U., von Hobe, M., Stroh, F., Sumin'skaEbersoldt, O., Volk, C. M., Hösen, E., Mitev, V., Shur, G., and Müller, R.: Heterogeneous chlorine activation on stratospheric aerosols and clouds in the Arctic polar vortex, Atmos. Chem. Phys., 12, 11095-11106, doi:10.5194/acp-12-11095-2012, 2012.

Winker, D. M., Vaughan, M. A., Omar, A. H., Hu, Y., Powell, K. A., Liu, Z., Hunt, W. H., and Young, S. A.: Overview of the CALIPSO mission and CALIOP data processing algorithms, J. Atmos. Ocean. Tech., 26, 2310-2323, 2009.

WMO: Scientific assessment of ozone depletion: 2014, Global Ozone Res., and Monit. Proj. Rep. 55, Geneva, Switzerland, 2014.

Wohltmann, I., Wegner, T., Müller, R., Lehmann, R., Rex, M., Manney, G. L., Santee, M. L., Bernath, P., Sumin'ska-Ebersoldt, O., Stroh, F., von Hobe, M., Volk, C. M., Hösen, E., Ravegnani, F., Ulanovsky, A., and Yushkov, V.: Uncertainties in modelling heterogeneous chemistry and Arctic ozone depletion in the winter 2009/2010, Atmos. Chem. Phys., 13, 3909-3929, doi:10.5194/acp-13-3909-2013, 2013. 